\title{
La visión del otro en el viaje de reconocimiento de la Costa del Seno Mexicano de José de Escandón (1747)*
}

\section{Resumen}

El descubrimiento de América y, posterior, proceso de expansión colonial hispana, generaron sendos viajes de exploración, por vía marítima o terrestre. Estas travesías generaron abundante información del paisaje, de la flora y fauna y de sus pobladores autóctonos. El artículo aborda el uso de estas fuentes en la historiografía, que explica ese proceso y reconstruye las características culturales de los aborígenes. Se busca hacer una revaloración crítica y debatir su utilidad, basándose en el diario de viaje elaborado por José de Escandón en 1747. Otro objetivo consiste en develar aquellas bases que influyeron en la descripción de los indígenas del Nuevo Mundo, con base en el enfoque de la otroedad. La indagación ha permitido plantear supuestos teóricos y metodológicos que posibilitan un análisis más reflexivo sobre las fuentes y su uso. Así como elementos para acceder a una mejor comprensión del significado y utilidad que la información recopilada tuvo en el contexto de sus autores.

\section{Palabras clave}

Tesauro: colonialismo, manuscrito, amerindio, visualización.

Autor: identidad cultural.

Referencia bibliográfica para citar este artículo: Olvera Chales, Fernando. "La visión del otro en el viaje de reconocimiento de la Costa del Seno Mexicano de José de Escandón (1747)". Anuario de Historia Regional y de las Fronteras 26.2 (2021): 255-286.

Fecha de recepción: $2 / 12 / 2020$

Fecha de aceptación: 18/03/2021

Fernando Olvera Charles: Doctor en Historia por la Universidad Nacional Autónoma de México. Investigador y catedrático del Instituto de Investigaciones Históricas; Unidad Académica Multidisciplinaria de Ciencias, Educación y Humanidades; instituciones dependientes de la Universidad Autónoma de Tamaulipas. Correo electrónico: carpiolvera@hotmail.com. Código ORCID: 0000-0002-3327-2550.

\footnotetext{
* El presente artículo forma parte de una indagación que tiene por objeto analizar la construcción de la imagen del nativo, que habitó el actual territorio de Tamaulipas, México, elaborada y difundida por militares y religiosos durante el siglo XVIII. Dicho estudio se deriva de un proyecto de investigación que el autor desarrolla, y que se intitula: Raíces culturales de la población actual de Tamaulipas. Es financiado por su centro de adscripción laboral.
} 


\section{The Vision of the Other in the Journey of Recognition of the Mexican Sine Coast of José de Escandón (1747)}

\section{Summary}

The discovery of America and, subsequently, the process of Hispanic colonial expansion, generated two exploration journeys, by sea or land. These journeys generated plenty of information about the landscape, flora and fauna, and its native inhabitants. The article discusses the use of these sources in historiography, which explains this process and reconstructs the cultural characteristics of Aboriginal people. It seeks to make a critical revaluation and debate its usefulness, based on the travel diary prepared by José de Escandón in 1747. Another objective is to uncover those foundations that influenced the description of the indigenous people of the New World, based on the approach of the other. The inquiry has made it possible to raise theoretical and methodological assumptions that allow a more thoughtful analysis of the sources and their use. As well as elements to access a better understanding of the meaning and usefulness that the information collected had in the context of its authors.

\section{Keywords}

Thesaurus: Colonialism, Manuscript, Amerindian, Visualization.

Author: Cultural Identity

\section{A visão do outro na jornada de reconhecimento da Costa do Sine Mexicano de José de Escandón (1747)}

\section{Resumo}

A descoberta da América e, posteriormente, o processo de expansão colonial hispânica, geraram duas viagens de exploração, por mar ou terra. Essas viagens geraram informações abundantes sobre a paisagem, flora e fauna e seus habitantes nativos. $O$ artigo discute o uso dessas fontes na historiografia, o que explica esse processo e reconstrói as características culturais dos povos aborígenes. Busca fazer uma reavaliação crítica e debater sua utilidade, a partir do diário de viagem elaborado por José de Escandón em 1747. Outro objetivo é desvendar as bases que influenciaram a descrição dos povos indigenas do Novo Mundo, a partir da abordagem do outro. A indagação possibilitou levantar premissas teóricas e metodológicas que permitam uma análise mais criteriosa das fontes e seu uso. Além de elementos para acessar uma melhor compreensão do significado e utilidade que as informações coletadas tinham no contexto de seus autores.

Palavras-chave

Thesaurus: Colonialismo, Manuscrito, Ameríndio, Visualização.

Autor: Identidade Cultural. 


\section{Introducción}

El descubrimiento del nuevo mundo por los españoles desencadenó una serie de viajes de exploración en los nuevos territorios de lo que sería el continente americano. La importancia de este tipo de viajes radica en que trasmitieron noticias y conocimiento de un mundo hasta ahora desconocido en la vieja Europa y otras latitudes del planeta. La información sobre nuevas culturas representadas por los grupos nativos que poco a poco fueron contactados, junto con la flora y faunas exóticas, acapararon las bitácoras de los navíos que surcaron el Atlántico para internarse en tierras desconocidas desde fines del siglo XVI hasta las postrimerías del imperio español en América. Desde los viajes de Magallanes que rodearon la parte del sur hasta las expediciones de Malaspina y Humboldt, las exploraciones jugaron un papel importante en la elaboración de la imagen del Nuevo Mundo y sus habitantes.

A la par de estas grandes travesías marinas, los derroteros por tierra complementaron dicha función pues dieron a conocer al resto del planeta, vía España, la existencia de diversas etnias y una variada flora y fauna endémicas de tales regiones. Un valor extra, es que tales viajes adquirieron otras dimensiones ya que la mayor parte de ellos antecedieron a sendos procesos de colonización, y sentaron las bases que orientaron el empuje hispano en América y la forma de tratar a sus pobladores autóctonos. Este es el caso del viaje de reconocimiento de José de Escandón realizado en 1747, en el territorio que actualmente ocupa el estado de Tamaulipas, México. Ampliamente referido en la historiografía local y nacional que aborda el proceso de colonización hispano del suelo tamaulipeco y los aspectos culturales y forma de vida de sus pobladores autóctonos, el viaje se aborda y se analiza desde otra perspectiva. Fuente de primera mano para reconstruir parte de la etapa colonial y también para definir, clasificar y caracterizar a los nativos que lo poblaron, poco se ha cuestionado acerca de la imagen que, sobre estos últimos, elaboró Escandón y la utilidad que dicha figura representó para el militar, que, posteriormente, se encargó de colonizar la zona en mención. Este artículo aborda este último aspecto y hace una revaloración crítica de la fuente al tiempo que analiza los códigos culturales y aspectos contextuales que influyeron en el peninsular al momento de delinearlos en su texto. De modo que se parte de los estudios que abordan la otroedad, es decir, de la definición del indígena como el otro por los europeos, para explicar parte de ese retrato.

Con base en este enfoque se ha desarrollado una línea de investigación muy productiva, la cual se ocupa en escudriñar, en las fuentes primarias, la forma en que sus autores han concebido al otro, la alteridad, es decir, lo diferente. Este estudio dialoga con esta corriente interpretativa y agrega un elemento más de análisis, como lo es el horizonte del autor y el contexto de la elaboración del manuscrito; aspectos relacionados con los fines prácticos que para ese momento representó el viaje referido. De ahí, que se postula también una interpretación sobre la intencionalidad e interés que tuvo el manuscrito de Escandón en su tiempo, revelándose aquellos elementos que nutrieron su pensamiento acerca de la población aborigen, el cual se develó por medio de las vivas descripciones que asentó en su derrotero. 


\section{La importancia del manuscrito y su uso en la historiografía}

Los estudios sobre el proceso fundacional de la Colonia de Nuevo Santander, actualmente Tamaulipas, México, son fecundos. Desde finales del siglo XIX, algunos historiadores locales abordaron la temática y aludieron la empresa colonizadora de José de Escandón, sin hacer referencia al citado diario de viaje de 1747. ${ }^{1}$ Parte importante del discurso elaborado sobre la etapa hispana del territorio en mención, el manuscrito de Escandón en el siglo venidero comenzó a ser referente del proceso colonizador que experimentó el espacio de estudio. Para inicios del siglo XX, el personaje fue motivo de un estudio que abordó su figura y participación en el proceso referido. El relato de nueva cuenta fue utilizado para reconstruir el contexto previo a la colonización y al asentamiento de los españoles. ${ }^{2}$ Este fue el arranque de los estudios de la época moderna sobre el militar y el acontecimiento histórico en que se vio envuelto. En los años subsecuentes de la centuria se elaboraron diversas obras que tuvieron como eje la historia de Tamaulipas. En estas visiones de corte general sobre el desarrollo histórico del estado, el abordaje de la etapa inicial del periodo hispano fue nutrido en parte con el citado manuscrito. ${ }^{3}$ Trabajos más especializados sobre la etapa colonial del territorio, que abordan el proceso fundacional, la política de poblamiento y las respuestas de los nativos al avance hispano, incluyen como parte de sus fuentes el viaje de reconocimiento. ${ }^{4}$

\footnotetext{
${ }^{1}$ Alejandro Prieto, Historia, Geografia y estadística de Tamaulipas (México: Tipografía Escalerillas núm. 3, 1873), 140-141. Toribio de la Torre y otros. Historia General de Tamaulipas (Cd. Victoria, Tamaulipas: Instituto de Investigaciones Históricas -Universidad Autónoma de Tamaulipas, 1986), 58-59. El manuscrito original procede de 1846 circa, y fue editado por primera vez en 1975. De la Torre hace alusión al viaje, sin mencionarlo tácitamente. En el prólogo es referido como uno de los documentos personales de Escandón, p. 9.

${ }^{2}$ Francis Lawrence Hill fue uno de los primeros en abordar la vida del fundador de la Colonia de Nuevo Santander. Hill, Francis Lawrence. José de Escandón and the founding of the Nuevo Santander (Ohio: State University Press, Columbus, 1926), 65-66. Posterior a la obra de Hill, el polifacético personaje ha sido objeto de varios estudios y biografías. Entre ellos están, Meade, Joaquín. Don José de Escandón, conde de Sierra Gorda (Monterrey: Universidad Autónoma de Nuevo León, 1948), p. 27-38, en línea: http://cdigital. dgb.uanl.mx/la/1020003895/1020003895.html. Canales Ruiz, Jesús. José de Escandón, la Sierra Gorda y el Nuevo Santander. (España: Institución Cultural de Cantabria-Centro de Estudios Montañeses-Diputación Regional de Cantabria, 1985), 62, 129-136.

${ }^{3}$ Gabriel Saldívar, Historia Compendiada de Tamaulipas (México: Gobierno del Estado de Tamaulipas, 1945), p. 81-83. Juan Fidel Zorrilla y otros, Tamaulipas. Una historia compartida I, 1810-1921 (México: Instituto de Investigaciones Históricas-Universidad Autónoma de Tamaulipas/Instituto José Luis María Mora, 1993), 14-15. Herrera Pérez, Octavio. Breve Historia de Tamaulipas (México: El Colegio de México/ Fondo de Cultura Económica, 1999), 64-65. En una de las obras más recientes, que aborda una visión muy amplia de la historia de Tamaulipas con base en sus regiones y municipios, Octavio Herrera también refiere de manera constante el viaje de reconocimiento. Herrera Pérez, Octavio. Tamaulipas a través de sus regiones y municipios. Tomos I-IX (México: Agencia Promotora de Publicaciones/Gobierno del Estado Libre y Soberano de Tamaulipas, 2014). Por ejemplo, en el apartado dedicado a Laredo del tomo I, que comprende la región norte, menciona la travesía de Escandón de 1747, 19.
}

${ }^{4}$ Israel Cavazos Garza, Nuevo León y la colonización de Nuevo Santander (Monterrey: Sindicato Nacional de Trabajadores de la Educación, 1994), 29-32. Osante, Patricia. Orígenes del Nuevo Santander, 1748-1772 (México: Universidad Nacional Autónoma de México/ Instituto de Investigaciones Históricas-Universidad Autónoma de Tamaulipas, 1997), 107-112. Gabriela Vázquez García, “José de Escandón y las nuevas poblaciones del Nuevo Santander", Scripta nova, X, 218 (85), Barcelona, Universidad de Barcelona, 2006, s/p. en línea: http://www.ub.edu/geocrit/sn/sn-218-85.htm. FernandoOlvera Charles, "Sobrevivir o 
Su utilidad no paro ahí, sino que se trasladó a uno de los aspectos más importantes que el coronel asentó en su viaje: los nativos del territorio. No obstante que desde el siglo XIX algunos autores aportaron datos sobre la población nativa, ${ }^{5}$ será hasta la segunda década del siglo XX cuando se elaboraron obras enfocadas en los pobladores autóctonos y sus características culturales. El manuscrito volvió a ser retomado para reconstruir parte de las características culturales de los primigenios habitantes del territorio, siendo usado en libros de corte etnológico y etnohistórico que tienen como estudio principal a dichos nativos. En este rubro se ha convertido en una referencia básica para aquellos estudiosos del pasado indígena de suelo tamaulipeco. ${ }^{6}$

La importancia del manuscrito en la historiografía sobre el proceso colonizador de la zona y sus pobladores nativos, de corte local o foráneo, evidenciada en líneas precedentes, ha trascendido a otros ámbitos. Su valor como fuente de primera mano sobre el pasado de la entidad tamaulipeca impulsó a ciertas personas

fenecer en el noreste novohispano". Estrategias de los indigenas ante la colonización y su incidencia en el comportamiento de la resistencia nativa en Nuevo Santander, 1780-1796. (San Luis Potosí: Colegio de San Luis/UAT, 2019), p. 27-32, 39, 57, 64. Por otra parte, el manuscrito de Escandón también ha proporcionado información para la elaboración de tesis de diversos grados. Cunningham, Debbie S. La exploración y colonización preliminar del Seno Mexicano bajo don José de Escandón (1747-1749): un análisis basado en manuscritos españoles primarios (Tesis doctoral), Texas A\&M University, 2010, en línea: http: // HDL. handle .net / 1.9690 .1 / ETD -TAMU -2010 -08 -8218. Esta tesis doctoral destaca pues se dedica en su totalidad a abordar el citado viaje de reconocimiento de Escandón. Contiene un capítulo dedicado a la historiografía existente en torno al personaje y el proceso colonizador, donde se privilegia el análisis del uso del manuscrito de 1747. Destaca también porque incluye otro capítulo donde se hace un análisis del manuscrito original, se paleografía y se trascribe al inglés. Fernando Olvera Charles, Las incursiones lipanes y comanches en Nuevo Santander, 1750-1800 (Tesis doctoral, UNAM, 2017), 25, 29, 33, 38.

${ }^{5}$ Alejandro Prieto, dedicó varios capítulos de su obra a los nativos del territorio.

${ }^{6}$ Saldívar, Gabriel. Los indios de Tamaulipas (México: Instituto Panamericano de Geografía e Historia,1943). Saldívar, no cita el diario de Escandón, sin embargo, se percibe que parte de la información que asentó en su obra fue tomada del citado manuscrito, por ejemplo, la referencia que hace al capitán indígena Santiago al que le confiere un amplio mando, véase la pagina 7. De hecho, al final de su texto señaló que la información recopilada fue tomada de documentos localizados en el Archivo General de la Nación, de México, de los Ramos de Provincias Internas y de Misiones, seguramente, se incluía el citado escrito de 1747. Eguilaz de Prado, Isabel. Los indios del Nordeste de Méjico en el siglo XVIII (Sevilla: Facultad de Filosofía y LetrasUniversidad de Sevilla, 1965). Cabe señalar que la autora refiere otro original u copia del manuscrito de Escandón, localizado en el Archivo General de Indias, de Sevilla, España. Lo cita como AGI, México 690. Test. Real Cedula, el cual contiene varios folios. Veas por ejemplo las paginas 11, 45, 47, 63, 91, 104. StresserPean, Guy, San Antonio Nogalar: la sierra de Tamaulipas y la frontera noreste de Mesoamérica (México: Centro de Investigaciones y Estudios sobre Antropología Social/Colegio de San Luis/Universidad Autónoma de Tamaulipas/Centro Frances de Estudios Mexicanos y Centroamericanos, 2000), 503, 531, 538, 542, 565, 567. Ramírez Castilla, Gustavo Antonio. Panorama arqueológico de Tamaulipas (Ciudad Victoria: Gobierno del Estado de Tamaulipas/Instituto Tamaulipeco para la Cultura y las Artes, 2007), 62, 6, 65, 66, 71,74, 80, $84,86,87$.

Salinas, Martin. Indigenas del delta del río Bravo. Su papel en la historia del sur de Texas y el noroeste de México. (Ciudad Victoria: Instituto de Investigaciones Históricas-Universidad Autónoma de Tamaulipas, 2012). El manuscrito es una fuente básica utilizada para reconstruir las características culturales de los pobladores autóctonos del citado río, por lo que el autor lo refiere constantemente, para ejemplo, véanse las siguientes páginas: 42, 60-63, 78-80. Cunningham, Debbie S. "Los nativos del Seno Mexicano documentados en los manuscritos de Escandón y Hierro de 1747-1749 (1)", en Southern Quarterly, 51, 4, Hattiesburg, University of Southern Mississippi, 2014 en línea: https://www.questia.com/library/journal/1P3-3524068251/ the-natives-of-the-seno-mexicano-as-documented-in. Respecto a este artículo es necesario aclarar que el sitio de la revista solo ofrece una vista previa, por tal razón, no se especifican las páginas. 
e instituciones a publicar el escrito original localizado en el Archivo General de la Nación, de la ciudad de México. Con esta acción se pretendió que su contenido fuera accesible a todo aquel historiador interesado en estas temáticas. Uno de los pioneros fue Gabriel Saldívar quien tuvo acceso al texto, y lo trascribió y editó en $1946 .^{7}$ Tiempo después, una nueva versión paleográfica de un borrador que sirvió de base al original fue editada en 1999 por el Consejo Estatal para la Culturas y las Artes del estado de Tamaulipas, México. ${ }^{8}$

Como se percibe en este somero análisis de cómo se ha empleado el documento, que versa sobre el viaje de reconocimiento que Escandón realizó en 1747, es claro que ha sido fuente indispensable para reconstruir parte de la etapa colonial que experimentó el territorio tamaulipeco actual y también para definir, clasificar y caracterizar a los nativos que lo poblaron. Como se postuló en la introducción, este ensayo aborda este último aspecto y hace una revaloración crítica de la fuente y de la imagen que se elaboró sobre ellos. Se analiza la producción de esa figura con base en la otroedad y la alteridad, aspecto no abordado hasta ahora en la fuente primaria en mención. Recurriendo a este enfoque, se ha desarrollado una importante historiografía que analiza diversas fuentes documentales de la época del descubrimiento y conquista, y del posterior desarrollo del imperio español en América; el estudio se inserta en esa línea. ${ }^{9}$ Así mismo, como se refirió, se ensaya una postura sobre la intencionalidad y utilidad que tuvo el diario de viaje de Escandón en su tiempo. Conviene aclarar que

\footnotetext{
${ }^{7}$ José de Escandón, Reconocimiento de la costa del Seno mexicano, Archivo de la Historia de Tamaulipas, $1^{\text {a }}$. serie, vol. 2 (México: Editor y compilador Gabriel Saldívar, 1946).

${ }^{8}$ En esta versión más reciente del manuscrito, que es una copia del original, destaca el estudio de autenticidad practicado por Rafael Vázquez Sánchez, perito grafoscopo, realizado en la ciudad de México en marzo de 1998, mismo que develó su originalidad. Escandón y Helguera, José de, 1747 Informe para reconocer, pacificar y poblar la Costa del Seno Mexicano. Introducción, paleografía y notas por Juan Díaz (Ciudad Victoria: Consejo Estatal para la Cultura y las Artes en Tamaulipas/Gobierno de Tamaulipas, 1999). En adelante se usará esta versión como referencia del diario del informe de Escandón que se analiza.

${ }^{9}$ Ejemplo de estos estudios son: Solodkow, David. M. "De caníbales, etnógrafos y evangelizadores: versiones de la Otredad en las primeras cartas del "Descubrimiento" (Cristóbal Colón [1493], Michele de Cuneo [1495] y Pêro Vaz de Caminha [1500])", en The Colorado Review of Hispanic Studies, 3 (2005): 1739, en línea: https://www.academia.edu. (25 de marzo de 2021); Carneirò, Sarissa, "Mujer y alteridad en los discursos lusitanos coloniales sobre Brasil del siglo XVI: reelaboraciones, desplazamientos", en Lucero, vol. 17, Berkely, Department of Spanish \& Portuguese-University of California, 2006, 88-97, en línea: https:// escholarship.org/uc/item/9rh5m4xp. (25 de marzo de 2021); Solodkow, David M. Etnógrafos coloniales: escritura, alteridad y eurocentrismo en la conquista de América. (Tesis doctoral), Vanderbilt University, 2009, en línea: https://ir.vanderbilt.edu/bitstream/handle/1803/11738/Solodkow.pdf. (25 de marzo de 2021); Pero Vaz de Caminha. Carta del descubrimiento de Brasil. Traducción del portugués y prologo por Isabel Soler. (Barcelona: Acantilado. Quaderns Crema, S.A.U, 2009); Mora Rodríguez, Luis Adrián. "Imaginarios del otro en la conquista. La construcción polimórfica del indio en la Apologética Historia Sumaria de Bartolomé de Las Casas”, en Realis, Revista de Estudos Antiutilitaristas e Poscoloniais, 5, 2, Recife, Programa de Pós-Graduação em Sociologia-Universidad de Federal de Pernambuco, 2015, 165189, en línea: https://periodicos.ufpe.br/revistas/realis/issue/view/1173/showToc. (25 de marzo de 2021); Lopes de Carvalho, Francismar Alex. "Imagens dos índios na Amazônia espanhola, nos séculos XVI e XVII”, en Revista de Indias, 78, 274 (2018): 687-733, en línea: https://doi.org/10.3989/revindias.2018.i274; Hernández Casillas, H., y Guevara Zárraga, M. E. "Las posibilidades del análisis crítico del discurso en el seguimiento de estructuras discursivas de dominación en documentos coloniales. El caso del Manifiesto de Eusebio Bentura Beleña, Nueva España”, en Antigua Matanza. Revista de Historia Regional, San Justo, Universidad Nacional de la Matanza, 4, 2 (2020): 156-188, en línea: http://antigua.unlam.edu.ar.
} 
no es el objetivo reseñarlo o darlo a conocer, aspecto ya trabajado, sino más bien hacer una valoración crítica sobre este tipo de fuentes para la historia, como son los viajes y su uso para reconstruir a sociedades pretéritas o procesos históricos. Previo a dicho análisis y abordar el marco teórico que nutre esta indagación, es momento de dar una semblanza sobre el autor del diario del viaje y el contexto que lo originó en 1747.

\section{Notas biográficas del coronel José de Escandón}

Como se refirió, el personaje ha sido objeto de varios estudios sobre su persona y su obra colonizadora. Con base en ellos se vierten lo siguientes datos biográficos. Oriundo de la península ibérica, nació en Soto la Marina, poblado cercano a la ciudad de Santander, provincia del mismo nombre. ${ }^{10}$ En los años de su juventud partió en 1715 al Nuevo Mundo en busca de fortuna, como muchos otros españoles de su tiempo. Los vientos del mar Atlántico lo llevaron al denominado virreinato de la Nueva España, arribando a la parte sureste, en la península de Yucatán. Ahí se enroló en la carrera de las armas e ingresó como cadete en una compañía de Mérida. ${ }^{11}$ Instalado en la ciudad de Querétaro hacia 1721, ubicada en el centro del virreinato, alcanzo el grado de sargento y en su calidad de Teniente de Milicias fue elegido para pacificar la Sierra Gorda; ${ }^{12}$ región que en ese tiempo representaba límites fronterizos con las zonas al margen del avance hispano. Sus logros en el ámbito del sometimiento de varias etnias de ese amplio espacio y el sofocamiento de varios alzamientos indígenas, que rechazan todo intento de ser reducidas a un régimen que colisionaba con su antigua forma de vida, le valió ser nombrado coronel del Regimiento de Milicias en 1740, y al siguiente, Teniente de Capitán General de la Sierra Gorda y sus fronteras. ${ }^{13}$ Destaca la refundación de varias misiones que, en poder de la orden de los agustinos, en 1744 pasaron a la injerencia de los franciscanos y el establecimiento de poblaciones duales, es decir, conformadas por españoles y nativos ya reducidos. ${ }^{14} \mathrm{Su}$ experiencia en el control y sometimiento de los aborígenes insumisos de espacios de frontera y sus nexos políticos con importantes personajes del virreinato, le permitió ser elegido para emprender la colonización y "pacificación" de la Costa del Seno Mexicano, (actualmente Golfo de México), territorio que permanecía al margen de la tutela española. Su nombramiento lo llevo a realizar un viaje de reconocimiento e inspección de ese amplio espacio, del cual solo existían

\footnotetext{
${ }^{10}$ Juan Fidel Zorrilla y Carlos Salas, Diccionario Biográfico de Tamaulipas (México: Editorial Jus/ Universidad Autónoma de Tamaulipas, 1984), 135-136. Juan Fidel Zorrilla, Familias políticas dominantes de Tamaulipas (Ciudad Victoria: Instituto de Investigaciones Históricas-Universidad Autónoma de Tamaulipas, 1996), 14. Saldívar, 78. Jesús Canales sostiene que su fecha de nacimiento fue el 19 de marzo de 1770. Canales 39. Su obra es de las más completas, pues dedica varios capítulos a rescatar los datos biográficos del personaje y de su familia, así como aspectos relacionados con su persona. Canales 33-83.

${ }^{11}$ Zorrilla y Salas 135-136. Meade 28. Zorrilla, Fidel 14; Saldívar, Historia Compendiada, 79.

${ }^{12}$ Meade, El conde de, 28. Zorrilla, Familias políticas, 15. La Sierra Gorda abarcó parte de los estados actuales de San Luis Potosí, Querétaro y Guanajuato, ubicados al noroeste de la ciudad de México.

${ }^{13}$ Joaquín. El conde de, 29.

${ }^{14}$ Lara Cisneros, Gerardo. El Cristo viejo de Xichú. Resistencia y rebelión en la Sierra Gorda durante el siglo XVIIII (México: Instituto de Investigaciones Históricas-Universidad Autónoma de Tamaulipas, 2007), 109-110.
} 
escasas referencias de la fisionomía del paisaje y de sus pobladores autóctonos. ${ }^{15} \mathrm{La}$ travesía de inspección inició el 7 de enero de 1757. Escandón partió de la ciudad de Querétaro, en ese entonces, su lugar de residencia. ${ }^{16}$ De ahí se dirigió a San Luis Potosí, pasó por Guadalcázar y llegó al precario asentamiento de Tula, y de ahí a Jaumave. En cada una de estas poblaciones Escandón incorporó más soldados a la tropa que lo acompañaba. Hasta ese punto contaba ya con 200 efectivos y un sargento, así como sirvientes e indios auxiliares, extendiéndose la expedición por espacio de tres meses. ${ }^{17}$ En ese lapso recorrió los cuatro puntos cardinales del territorio actual tamaulipeco. Para mayor referencia véase el mapa al final de este apartado.

Es importante destacar que la marcha formaba parte de un plan para ocupar la zona en mención. La idea de colonizar y "pacificar” el área era muy añeja, remontándose a los años veinte del siglo XVIII. No obstante, el medio agreste, las dificultades para reducir a sus comunidades autóctonas y la ausencia de minas desalentaron los intentos, al grado de retrasarse mucho el proyecto. La presencia de las potencias extranjeras, Francia e Inglaterra, que con fines expansionistas amenazaban los extremos septentrionales del virreinato de la Nueva España, y el hecho de que la Costa del Seno Mexicano permaneciera sin "poblar", los volvían puntos vulnerables. Hacia inicios del citado siglo el dominio hispano había ocupado en su totalidad el territorio que rodeaba a la Costa, formando esta última una especie de bolsón, ocupado por distintos grupos indígenas, sustraídos al virreinato. ${ }^{18}$ En ese lapso, el avance hispano ocupaba los territorios adyacentes. Las provincias contiguas, Pánuco, Nuevo Reino de León, Coahuila y Texas, fundadas hacía tiempo, acentuaban la marginalidad de la Costa. Con el objetivo de convertir la franja en baluarte defensivo y reducir a sus habitantes autóctonos, las autoridades novohispanas decidieron consumar su "pacificación" y colonización a mediados de la centuria, por lo que aprobaron la propuesta del coronel Escandón para afianzar el dominio del Seno Mexicano. El proyecto comprendía varios objetivos. Uno de ellos era poblar el noreste extremo y protegerlo ante cualquier intento de apropiación por parte de potencias extranjeras. Se buscó asimismo contener a los indígenas apaches que incursionaban a la sazón en Texas. Finalmente, existía la idea de explotar las ricas tierras de la zona, como las situadas entre los ríos Bravo y de las Nueces. ${ }^{19}$ Previo reconocimiento en 1747 , y seleccionados los parajes donde fundar los vecindarios, al siguiente año, el militar inició la ocupación formal y fundó la Colonia de Nuevo Santander. ${ }^{20}$

\footnotetext{
${ }^{15}$ Zorrilla, Familias politicas, 16. Escasos fueron los contactos previos con el territorio y sus pobladores autóctonos, los pocos conocimientos se derivaron de algunos viajeros y comerciante que, desafiando a las etnias de la zona, cruzaron su parte central para establecer una primigenia ruta comercial entre el Nuevo Reino de León y la Huasteca. Osante 81.

${ }^{16}$ En su derrotero el coronel Escandón fue apoyado por los gobernadores y militares de las provincias cercanas a la Costa del Seno Mexicano, Escandón y Helguera, José de, 1747 Informe para, 36. Canales, José de Escandó, 131.

${ }^{17}$ Canales 132-134.

${ }^{18}$ Olvera, Incursiones lipanes, 40-41; Olvera, Sobrevivir o fenecer, 33.

${ }^{19}$ Escandón y Helguera, 1747 Informe para, 18.

${ }^{20}$ Olvera, Incursiones lipanes, 40-41.
} 
Descritos los rasgos biográficos del personaje y develado el contexto que causó el viaje que se aborda, es momento de ocuparse del andamiaje teóricometodológico que guía este estudio, relacionado con la manera en que los nativos americanos han sido definidos, para, posteriormente, analizar la imagen que Escandón elaboró sobre los habitantes originarios de la Costa del Seno y explicar el sentido y utilidad que el informe generó para el autor, para su tiempo y para el proceso histórico que lo envolvió: la colonización de Nuevo Santander.

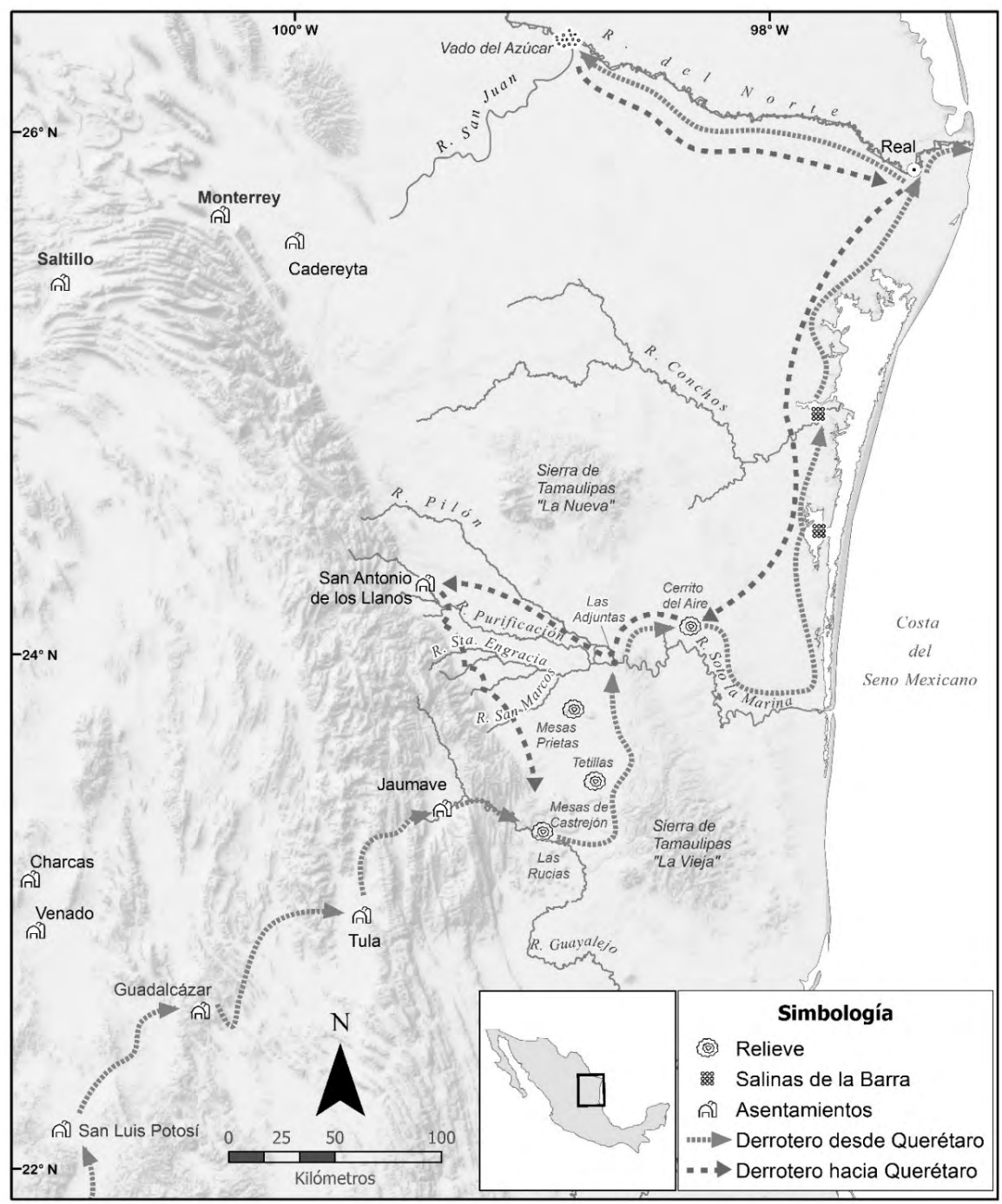

Mapa del derrotero de José de Escandón (1747=

Mapa basado en los datos asentados en Escandón y Helguera, elaborado por Ana Gabriela Arreola Meneses por encargo de autor. 


\section{Elaboración de la imagen de los habitantes del nuevo Mundo}

El descubrimiento del continente, a la postre, denominado América, y la posterior expansión y ocupación española de sus extensos territorios, originó diversas definiciones y visiones sobre sus pobladores autóctonos. Un imaginario de larga tradición europea que definía aquellas personas con características culturales, diferentes, a lo que se concebía como civilizado, influyó para que fueran denominados de manera amplia como "bárbaros y salvajes". Dicha mirada se nutrió también de las respuestas de los aborígenes al proceso de exploración y conquista, así como de su talante y apariencia física. Epítetos como "indios de guerra", "indios de paz", "apostatas", "cristianos", "reducidos", "auxiliares", y "amigos", se derivaron de su aceptación o rechazo de las condiciones impuestas por los españoles. ${ }^{21}$ Tales distinciones rondaron en el imaginario de aquellos expedicionarios y conquistadores de las tierras al norte de la Nueva España, cuyo trato con los nativos de esa amplia región nutrió y alimentó esas visiones en los siglos venideros. Estas definiciones originaron categorías político-sociales, elaboradas por los hispanos, que pretendían ubicar la posición que ocupaban los autóctonos dentro del sistema colonial. De acuerdo con su posición asumida ante el proceso referido, si se reducían o congregaban en pueblos y misiones eran considerados como parte de ese sistema, si, por el contrario, se resistían, se les veía como enemigos y ajenos a la estructura. Por tanto, debían ser incorporados, o en el peor de los casos, exterminados para no dilatar su desarrollo y el afianzamiento del dominio español. Para el siglo XVIII la concepción del nativo, por un lado, enemigo de los españoles, por otro, dócil y cooperativo, había arraigado en el imaginario de las autoridades y personajes involucrados en la "pacificación" de los territorios norteños. ${ }^{22}$

\footnotetext{
${ }^{21}$ Salvador Álvarez, citado por Sara Ortelli, apunta que "la identificación de grupos enemigos sucedió varias veces en el ámbito americano desde la llegada de los españoles”. Desde principios del siglo XVI, los denominados los caribes fueron declarados "enemigos de la corona", situación que más tarde se extendería también a otros nativos denominados como chichimecas, los tobosos y los apaches. Se convirtieron "en algo así como sinónimos de indios de guerra”. Ortelli, Sara. “AApaches hostiles, apóstatas rebeldes o súbditos infidentes? Clasificaciones etnopolíticas en la Nueva Vizcaya de la segunda mitad del siglo XVIII" en Anuario, núm. 21, Buenos Aires, Instituto de Estudios histórico-sociales, 2006, 84, en línea: http://anuarioiehs.unicen.edu.ar/Files/2006/. Jesús Bustamante plantea que desde "el punto de vista visual existen al menos cuatro grandes arquetipos sobre el indio americano, que fueron surgiendo desde principios del siglo XVI", presentes hoy en día. Las considera no incompatibles ni excluyentes entre ellos, a pesar de que cada uno tenga implicaciones sociales y políticas muy distintas. Estos son: "El Salvaje emplumado", "el indio a la romana", "el indio vecino" y el "bárbaro sanguinario", Bustamante, Jesús. "La invención del indio americano y su imagen: cuatro arquetipos entre la percepción y la acción política", en Nuevo Mundo Mundos Nuevos, Debates, 2, 14, 24, 32, 37. en línea: http://journals.openedition.org/ nuevomundo/71834;DOI: https://doi.org/10.4000/nuevomundo.71834.

${ }^{22}$ El "bárbaro sanguinario", postulado por Bustamante, podría ser encajar en la imagen del nativo de Nuevo Santander que delineó Escandón. De acuerdo con el autor, "Nacido hacia finales del siglo XVIII, el Bárbaro Sanguinario es el arquetipo más reciente del indio americano y uno de los más extendidos dentro y fuera del continente". Argumenta que, según las distintas geografías y procesos históricos sus características varían, no obstante, todas sus variantes comparten rasgos comunes: "condición incívica, casi ferina, y violenta en grado extremo", Álvarez 37-44.
} 
El estudio de la otroedad, de la alteración o lo diferente, ha generado importantes conocimientos sobre lo anterior, ya que se especializa en las formas o maneras en que los españoles conceptualizaron, catalogaron y definieron a los habitantes originarios del continente americano. Es un campo de estudio fecundo donde se han postulado argumentos puntales, y destacan importantes autores que son referentes en la temática. ${ }^{23}$ Teniendo como marco referencial el descubrimiento del Nuevo Mundo, se analizan los códigos y parámetros culturales de larga tradición europea que subyacen detrás de la concepción del nativo. ${ }^{24}$ El enfoque teórico analítico con que se aborda la mirada sobre el ajeno retoma parte de los argumentos que pautan los estudios sobre la cuestión. En ellos se postula que el otro representó un problema para el europeo al momento del descubrimiento del Nuevo Mundo, y posterior colonización hispana. ${ }^{25}$ Ese "Otro diferente", incluyendo su cuerpo, lengua, cultura y religión, generó una interrogante al "sí mismo" europeo, que, a la vez que domina, impone límites a su propio discernimiento. ${ }^{26}$ Así, se argumenta que la Conquista develó al otro, lo descubrió, lo sustrajo de su invisibilidad. ${ }^{27}$ Otro argumento revierte esta mirada y sostiene que, al contario, dicho proceso encubrió, borró, alteró, la naturaleza del hombre americano. Se le percibe como un proceso de "en-cubrimiento" de lo no-europeo". ${ }^{28}$ En ese acontecimiento el "Otro de Europa" fue motivo de la "más intricadas especulaciones de un tipo específico de discursividad colonial", denominado escritura etnográfica. ${ }^{29}$ Para algunos ese hecho coyuntural presenta una ambigüedad: la revelación de la alteridad humana y su negación a la vez. ${ }^{30}$ Para otros, abrió un debate en torno la contraposición, o contraste, entre el salvaje, definido como "inculto y melancólico" y el "ciudadano", percibido como "apacible y humano, dulce y sociable". ${ }^{31}$ Otra postura lo relaciona con el "nacimiento" de la Modernidad como concepto, visualizando a la Alteridad como constitutiva de la misma. ${ }^{32}$

\footnotetext{
${ }^{23}$ Tzvetan Todorov, La Conquista de América el problema del otro (México: Siglo XXI Editores, 1998). Josep Fontana, Europa ante el espejo (Barcelona: Editorial Critica, 2000). Enrique Dussel, 1492 El encubrimiento del Otro. Hacia el origen el mito de la modernidad (La Paz: Plural Editores/Universidad Mayor de San Andrés, 1994) Roger Bartra, El salvaje en el espejo (México: Universidad Nacional Autónoma de México/ Era, 1992, Solodkow, David M. Etnógrafos coloniales: escritura, alteridad y eurocentrismo en la conquista de América. (Tesis doctoral, Vanderbilt University, 2009). Rossana Reguillo, "El otro antropológico. Poder y representación en una contemporaneidad sobresaltada", en Anàlisi, Quaderns de Comunicació i Cultura, 29 (2002) en línea: https://core.ac.uk/download/pdf/13267366.pdf (25 de marzo de 2021).

${ }^{24}$ Fontana 105; Bartra 98.

${ }^{25}$ Todorov 13-14

${ }^{26}$ Solodkow 2-3.

${ }^{27}$ Todorov $13-14$

${ }^{28}$ Dussel 8- 31 .

${ }^{29}$ Se le define como un "espacio textual en el que se diseminan un conjunto de reglas de formación discursiva que colaboran mutuamente para construir la diferencia cultural, la negación/creación de la alteridad, la producción del saber sobre el Otro y la construcción de nuevas identidades sociales y raciales". Solodkow, David. M. 3.

${ }^{30}$ Cristóbal Colón, por ejemplo, elaboró dos imágenes contrastantes del otro: la del "buen salvaje", y la del "pobre perro", ambos mitos tienen su base en el desconocimiento de los indios y de aceptar que, como sujetos, tiene derechos iguales al genovés, pero, diferentes. Todorov 44.

${ }^{31}$ Fontana 108.

${ }^{32}$ Dussel 31.
} 
Por otro lado, se sostiene que ese otro se puede descubrir dentro de uno mismo, y concebirse como una "abstracción o una instancia de la configuración psíquica de toda persona, como el "Otro". ${ }^{33}$ De este modo, "lo Otro" como "lo mismo", se argumenta, formarían parte de una estructura que se complementa, no siendo posible definir "lo mismo" sin asumir lo "Otro", mucho menos catalogar la diferencia sino se parte de un criterio de identidad (lo mismo). ${ }^{34}$ En este sentido, se recurre a la alegoría del espejo para sostener que el otro, el salvaje, es concebido como un cristal por los europeos, donde se miraron a sí mismos para definirse y reafirmar su identidad..$^{35}$ De ahí que se argumenta que todos los hombres se precisan a sí mismos mirándose en el espejo de «los otros», para diferenciarse de ellos. ${ }^{36}$ Por tanto, se postula que la presencia de un otro diferente y diferenciado resulta necesaria para las culturas europeas, para pensarse a sí mismas. ${ }^{37}$ Reforzando estas ideas se añade que el "otro hombre", denominado civilizado, no se ha desplazado sin ser acompañado de su sombra, el "hombre salvaje", de ahí que se postule que los europeos que descubrieron y colonizaron a América, lo trajeran consigo. ${ }^{38}$

Así, fue importado con el fin de que su ego no se disolviera en la asombrosa otroedad que descubrían. ${ }^{39}$ Tal figura, el "otro salvaje", es concebida, generalmente, como emanada del proceso colonizador hispano, una expresión euro centrista del empuje colonial que produjo una visión exótica y racista de los nativos que los conquistadores europeos encontraron y sometieron. ${ }^{40}$ Esta apreciación es debatida, sosteniéndose que, contrario a lo que se cree, la cultura europea construyó una imagen del "hombre salvaje" muchos años antes del descubrimiento. Por tanto, se le define como un ser europeo. ${ }^{41}$ De ahí que la "noción de salvajismo", se señala, fuera aplicada a las poblaciones no europeas, mediante una trasposición de un mito cabalmente estructurado, cuya esencia solo se comprende como parte del desarrollo de la cultura occidental. ${ }^{42} \mathrm{Al}$ presente, la comunicación global, se postula, volvió visible la diferencia, que se percibe como una «diferencia situada» eterna. Por tanto, adquirirá su significado desde un sitio, o el lugar que se establece como punto de frontera de esa disimilitud. Un espacio público expandido, se argumenta, se genera trastocándose ahí la idea del «salvaje» (interno y externo), ya que introduce y recircula "nuevas" representaciones sobre la otredad..$^{43}$

\footnotetext{
${ }^{33}$ Todorov 13.

${ }^{34}$ Solodkow 21

${ }^{35}$ Sin embargo, tal espejo en el que se han mirado para definirse presenta una doble cara: en una afloran las diferencias de raza y se devela el rostro del "salvaje", en la otra, apoyada en una visión de eurocéntrica del pasado se percibe al "primitivo", Fontana 107.

${ }^{36}$ Fontana 107. La dificulta de definirse a sí mismos, llevo a los griegos a idear el concepto de "bárbaro", como un espejo en el cual mirarse.

${ }^{37}$ Reguillo, Rossana, "El otro antropológico..., 66.

${ }^{38}$ Bartra 8, 13.

${ }^{39}$ Bartra 13.

${ }^{40}$ Bartra 8.

${ }^{41}$ Bartra 8, 13.

${ }^{42}$ Bartra 13.

${ }^{43}$ Reguillo 70-71.
} 


\section{Los nativos de la Costa del Seno Mexicano desde la visión del coronel}

Desde los preparativos del viaje es posible inferir el pensamiento e ideas de José respecto al otro. En una carta que escribió al virrey Horcasitas en marzo de 1747, señaló la necesidad de que ondeara el estandarte de la Santa fe entre la "multitud de indios, que infelizmente, como bárbaros salvajes habitan aquel incognito terreno". ${ }^{44}$ Distinguió de entre estos a los denominados “apostatas rebeldes", quienes, a su juicio, debían ser apresados y expulsados de las sierras del territorio, considerada zona de refugio. Así mismo, previo la existencia de "indios de paz", quienes saldrían de todas partes a recibir a los españoles ${ }^{45}$. Al principio de su viaje alude la presencia de indios bárbaros en las cercanías del precario asentamiento de Jaumave, lugar que denomina "último punto de la cristiandad" ${ }^{46}$ En su concepción distingue entre aquellos nativos, que define como "amigos" de los hispanos, de los que se negaron a rendirse y "darse de paz". Los primeros cumplen la función de auxiliar a la tropa y personas que lo acompañaron en el viaje, servir de intérpretes y guías. En las primeras páginas de su diario enuncia dicha categoría cuando descendió al Valle de las Rucias, al referirse a ciertos nativos que llegaron en compañía del capitán Francisco de Barberena y otro militar, procedentes de la villa de Valles y del valle del Maíz, respectivamente. ${ }^{47}$ Las concepciones anteriores saldrán a relucir en los reportes de los encuentros que tuvo el militar con los pobladores autóctonos habitantes de la Costa del Seno, y le servirán de base para etiquetar a los que presentaban ciertas características o contrastes de las calidades referidas, con la finalidad de darles sentido de existencia en su mundo hispano. Los casos siguientes ilustran su aplicación y revelan la idea preconcebida de los aborígenes que se forjó el colonizador.

En uno de los primeros encuentros, en un lugar denominado Valle del Cerrito, ubicado en el centro del territorio, Escandón parte de la citada categoría de "indios bárbaros" para definir a un grupo de 30 aborígenes que habitaban esa zona, a quienes calificó de apacibles. Según su testimonio, luego del contacto "regresaron muy contentos" a su ranchería localizada en la sierra denominada Tamaulipa Vieja. ${ }^{48}$ Si su respuesta fue así, ésta no encajaba en el patrón referente, por lo que colonizador

\footnotetext{
${ }^{44}$ Escandón y Helguera 17. El concepto de "bárbaro" fue acuñado por los griegos ante la dificultad que representaba dotarse de identidad cultural, siendo concebido como "el espejo en el cual mirarse para distinguirse a sí mismos", Fontana 11.

${ }^{45}$ Escandón y Helguera 18-21. Retomando a Fontana, Escandón distingue al otro, el indígena "bárbaro", del otro "apostata" que compara con el otro "hereje" o "infiel". Fontana, Josep 56.

${ }^{46}$ Escandón y Helguera 27. Esta alusión de frontera entre lo "cristiano" y lo "bárbaro", de acuerdo con Josep Fontana, tiene orígenes muy remotos. El mundo experimentó tensiones sociales y religiosas al inicio del año mil d. C., que llevaron al establecimiento de unas fronteras externas que dividieron a los musulmanes de Europa y de la cristiandad oriental. Este repliegue, postula el autor, se sustentó en la elaboración de una imagen distinta del "otro", que "debía ser excluido y combatido", es decir, la del "el hereje" y el "infiel, dos figuras que remitían a un mismo rostro, "el del diablo", que subyace detrás de ambas apariencias. Fontana, Josep. Europa ante..., 56.

${ }^{47}$ Escandón y Helguera 28-29.

${ }^{48}$ Escandón y Helguera 30. Actualmente se nombra Sierra de Tamaulipas, la que, junto con las sierras de San Carlos y Madre Oriental, conforman los macizos montañosos del territorio actual tamaulipeco.
} 
no dudó en aplicarles ese calificativo de "dóciles". En otro lugar, cercano al valle, el colonizador contacto a otros nativos que, a diferencia de los anteriores, agrupó en el concepto de "nación". Los identificó con el nombre de "Bocasprietas", y asentó que su capitán dijo llamarse Santiago, datos tomados seguramente de los intérpretes que lo acompañaban. Quizás por el tamaño de la etnia, cuyo número calculó en 400 familias, o por informes de estos, el colonizador hizo tal distinción. ${ }^{49}$ Según su testimonio, el líder nativo y muchos de sus congéneres, concurrieron de paz y pernoctaron en el Real, “con gran satisfacción", ofreciéndole Santiago convocar a todas sus rancherías. Al amanecer, Escandón reportó que habían llegado bastantes de ellos, previo a su partida, y que les ofreció regalos que los dejaron "muy contentos" y seguros que no se les dañaría. ${ }^{50}$ Dialogó con ellos sobre su incorporación al proceso colonizador y su asentamiento y, según parece, lo harían prontamente si era en ese sitio, no en otra parte. Tras prometerles que así lo haría, les ordenó que se mantuvieran de paz con indios y españoles, cumpliéndolo hasta la fecha de la conclusión de su viaje..$^{51}$ No obstante, de las muestras de afecto, para Escandón estos nativos cumplían cabalmente con la definición de "indios bárbaros" pues algunos de sus aspectos como andar desnudos, vivir en los montes y estar en guerra continua con otras etnias, lo llevo a señalar que:

Esta nación de boca prietas a lo que puede calcular tendrá 400 familias, son verdaderamente bárbaros, no tienen chozas, ni otra cosa alguna, qué la libertad del sol, y el agua, y por lo común, andan en cueros enteramente, a excepción de las mujeres, que usan poner un pedazo de cuero de venado o hierba, no siembran cosa alguna, comen de la caza y pesca, cogollos de palma y raíces silvestres. $^{52}$

La referencia de esta cita sobre su vestimenta: "andan en cueros enteramente", es una alusión frecuente en el manuscrito de Escandón que, como se verá en la siguiente cita, vuelve a enfatizar señalando que "andan totalmente desnudos", ${ }^{3}$ símbolo que condicionaba la visión sobre el otro. Como postula Todorov, desde los primeros contactos con los habitantes del nuevo Continente la desnudez fue resaltada y despertó la crítica de los europeos. Los indios desnudos fueron percibidos como "despojados de toda propiedad cultural", simbolizando la ausencia de costumbres, ritos y religión. ${ }^{54}$ En la Carta del descubrimiento del Brasil, elaborada por, Pero Vaz de Caminha en 1500, se percibe que el cuerpo desnudo de los aborígenes, de acuerdo con Sarissa Carneirò, es visto como signo interpretable de "un modus vivendi", cierto

\footnotetext{
${ }^{49}$ Escandón y Helguera 31.

${ }^{50}$ Escandón y Helguera 31.

${ }^{51}$ Escandón y Helguera 31.

${ }^{52}$ Ortelli postula que ciertos gentilicios, como el de bárbaros, "hacen referencia, básicamente, al modo de vida que caracterizaba a los nómadas y seminómadas, o a los grupos no integrados formalmente al sistema colonial y considerados como bárbaros y salvajes. Un discurso que exacerbaba el terror acompañó el proceso de interacción con estas sociedades desde los primeros momentos del avance de los españoles hacia el norte", Ortelli 87-88.

${ }^{53}$ Escandón y Helguera 41.

${ }^{54}$ Todorov 44.
} 
grado de civilización y una posición teológica determinada. ${ }^{55}$ Por otra parte, resaltar tales características y calificarlos como "verdaderamente barbaros", retomando a David Solodkow, conlleva a el conocimiento "del/sobre/contra el Otro", acerca de su cuerpo, sus creencias, sus prácticas; que está perpetuamente envuelto "en las relaciones de poder y, generalmente, es usado para controlar la conducta social recurriendo a prácticas discursivas, como, la etnografía y no discursivas, como la esclavitud. ${ }^{56}$

El siguiente grupo de aborígenes avistado fue los que habitaban en la zona occidental de las Salinas de la Barra, particularmente en las riberas del río Conchas. ${ }^{57}$ Semejante a los anteriores los agrupó en cuatro "naciones" con un nombre definido: pintos, pamoranos, quedejeños y quinicuanos, compuestas por alrededor de 150 familias. Registró como su capitán general a un nativo de nombre Marcos de Villanueva, quien, a decir de Escandón, era cristiano y había contraído matrimonio en la provincia contigua del Nuevo Reino de León, lugar al que solía asistir por temporadas. Al parecer, este ya había instruido de la llegada del militar a sus congéneres y su propósito, por lo que los referidos solicitaron la fundación de una población en ese lugar para congregarse. ${ }^{58}$ A ellos se agregarían otros, que encuadró en la que denominaban la nación Comecrudo, de igual número de parentelas. En este caso, su capitán fue llamado Marcos de la Cruz por Escandón. Al visitar su ranchería cercana al sitio, dichos nativos le ofrecieron alimento consistente en pescado crudo y asado. El coronel correspondió con regalos, como lo había hecho con los que se relacionó anteriormente. ${ }^{59}$ De nueva cuenta hace énfasis en la respuesta positiva de los aborígenes al decirles los beneficios que la fundación de una población hispana les traería en lo espiritual y temporal, y su congregación. Estos le respondieron que lo harían prontamente, y estarían en paz sin hacerle daño a nadie. ${ }^{60}$

Otro caso es el de los grupos indígenas que poblaron ambas márgenes del río Bravo, ubicado al norte de la Costa del Seno. Escandón asentó que el nativo que identificó como su líder llegó a esa zona para encontrarse con él, proveniente de la villa de Linares, ubicada en la contigua provincia, ya citada, en compañía de algunos pobladores e indios intérpretes de ese asentamiento. Fue llamado Santiago por el colonizador y definido como un "indio bárbaro", que era temido y respetado por sus congéneres y "muy afecto a los españoles”. Santiago por medio de señales de humo convocó a sus congéneres, quienes empezaron acercarse al Real que instaló el coronel. ${ }^{61}$ Según parece, le obedecían todos los nativos del citado torrente, desde el

\footnotetext{
${ }^{55}$ Vaz de Caminha fue un explorador y escritor portugués, y fungió como escribano en la flota de Pedro Álvares Cabral, descubridor de Brasil. Carneirò 89. La acentuación de la desnudez, según parece, fue una constante en las fuentes coloniales provenientes de diversas partes de América. En dicha carta este aspecto de los indígenas es referido reiteradamente, e influye en la visión que su autor se forja de los nativos.

${ }^{56}$ Solowkod 14.

${ }^{57}$ Escandón y Helguera 34.

${ }^{58}$ Escandón y Helguera 34-35.

${ }^{59}$ Escandón y Helguera 34-35.

${ }^{60}$ Escandón y Helguera 41.

${ }^{61}$ Escandón y Helguera 36-37.
} 
río San Juan hasta su desembocadura en el Golfo. Destacó que, a pesar de cada una de esas naciones indias tenían un cabecilla particular, Santiago fungía como capitán general de todas ellas y, según parece, lo obedecían. ${ }^{62}$ El líder apoyó al colonizador en su expedición de reconocimiento de la desembocadura del río Bravo en el mar. A su regreso al Real, Escandón señaló que más de 200 familias de nativos de las dos márgenes del río ya lo esperaban, respondiendo al llamado de Santiago. ${ }^{63}$ De las etnias contactadas Escandón identificó algunas por sus nombres, según parece, de origen indígena. Dato importante es que asentara que sus capitanes asistieron con mucha alegría y satisfacción, y juntaron una buena caza de venado, aves y pescado y se la ofrecieron en correspondencia por el buen trato que recibieron. ${ }^{64}$ Como resultado, destacó Escandón, algunos de ellos lo acompañaron en su regreso a las "Salinas de la Barra", junto con el referido capitán Santiago ${ }^{65}$. En cuanto a su congregación, el colonizador asentó que dichos nativos "estaban bien dispuestos" por lo que no había duda de su reducción, poniendo como única condición que no fueran removidos de la zona por haber nacido y crecido en allí. Además, los calificó como incapaces de hacer daño en las fronteras del Nuevo Reino de León. ${ }^{66}$ Una vez más registró una descripción de su persona:

Andan todos estos indios totalmente desnudos, a excepción de las indias, que se tapan con un pedazo de cuero y algunas yerbas; son corpulentos, ágiles y buenos tiradores de flecha, que son las únicas armas que usan y como no han tenido ningún comercio en las fronteras, se mantienen bozales, sin ley ni adoración a cosa alguna ninguna, por lo que hago juicio entrarán con gran facilidad en los rudimentos de Nuestra santa fe católica. ${ }^{67}$

\footnotetext{
${ }^{62}$ Escandón y Helguera 41.

${ }^{63}$ Escandón y Helguera 37-39.

${ }^{64}$ Escandón y Helguera 41.

${ }^{65}$ Escandón y Helguera 41.

${ }^{66}$ Escandón y Helguera 41. Este testimonio es citado por Gustavo Ramírez, como parte de las descripciones que se han elaborado de los nativos de la Costa del Seno, particularmente de la región del río Bravo, desde el siglo XVIII al XX. Crítica tales apreciaciones sobre los nativos, las que considera muy generalizadas, e incluso, erróneas, pues no posibilita poder apreciar el desarrollo que estos alcanzaron, ni observar rasgos más mundanos, su forma de vida o costumbres, por ejemplo. Ramírez 62-64.
}

${ }^{67}$ Escandón y Helguera 41. De acuerdo con Álvarez, este tipo de visiones en torno de los nativos norteños obedecieron más a las "nociones e ideas" que los hispanos se formaron sobre la geografía del Norte, que a una cuestión "etnográfica", como la "antropografía”, por ejemplo, colgada a los indios tepehuanes. Álvarez, Salvador. El indio y la sociedad colonial norteña, siglos XVI-XVIII (México: Colegio de Michoacán/ Instituto de Investigaciones Históricas-Universidad Juárez del Estado de Durango, 2009), 19. En contraste, Carlos Manuel Valdés postula que, en los escritos de militares y misioneros que recopilaron datos sobre la población nativa de Coahuila, es posible encontrar información que podría ser analizada como etnografía, pues se propusieron "describir un grupo al que reconocían como una cultura diferente". Valdés, Carlos Manuel. Los bárbaros, el rey y la iglesia (Saltillo: Universidad Autónoma de Coahuila, 2017), 37. Tomando el caso de Pérez de Ribas y otros cronistas, postula, que: "resulta evidente que las descripciones que hacen de los indígenas no son etnología, si son, en cambio, etnografía", 41 
Para concluir, otro grupo de nativos a que se refirió el militar fueron los que habitaban en el Cerro de Tamaulipas. Señaló que en sus faldas se asentaban varias rancherías de "indios barbaros" que, según sus informantes, pasaban de 1800. Los identificó como miembros de la "nación” Janambres, y que cada una de ellas tenía un capitán, no existiendo algún líder o cabeza general. Asentó que con ellos habitaban indígenas que denominó "apostatas", quienes provenían de la provincia aledaña, cuya serranía les servía de refugio para sus "insultos". ${ }^{68}$ En este caso, el militar no los contactó personalmente, los datos anteriores le fueron informados. Distinguió entre esas rancherías, dos etnias que habitaban en la parte oriental de la Tamaulipa, que con las que Escandón tuvo encuentros; mismas que denominó Pasitas y Chapoteños. Las diferenció de los Janambres porque la primera "mostro gran docilidad y afecto" a los españoles, era la única que sembraba algo de maíz, no hacían daño a nadie y vivían en chozas. La segunda, porque su capitán o líder indígena con algunos de sus congéneres fue a su encuentro en las Salinas de la Barra, lo auxilió en su inspección y sirvió de interprete. Según Escandón, el cabecilla se comprometió a congregarse con toda su gente y que procuraría que lo hicieran las demás etnias de la zona ${ }^{69}$ Delineada la imagen de los nativos de la Costa del Seno que elaboró Escandón, cabe preguntarse ¿qué elementos nutrieron su visión? ¿de qué bases culturales partió para definir así a los nativos?

Las categorías político-sociales, antes referidas, formaron parte de los elementos que alimentaron la visión de los nativos del Nuevo Santander elaborada por Escandón, descrita líneas arriba; imagen que se nutrió también de su propia experiencia en el control y sometimiento de etnias alzadas en zonas de frontera del dominio hispano, como lo fue la Sierra Gorda. Sumado a ello, la concepción del nativo se alimentó también del horizonte cultural que permeaba el contexto del coronel, ${ }^{70}$ que le hacía distinguir entre tierra de cristianos y de gentiles, colocando en esta última a los pobladores autóctonos del espacio abordado. Esta idea es reforzada en una expresión que asentó al final del informe de su viaje. Señaló que en el estado en que se hallaba el territorio explorado, las almas de los nativos se encontraban

\footnotetext{
${ }^{68}$ Escandón y Helguera 50-51. En este contexto el término "apostatas" se usó por los españoles para referirse a aquellos nativos que se habían congregado en misión y la habían abandonado, por lo que ya habían tenido algún contacto con las creencias cristianas occidentales.

${ }^{69}$ La diferencia que hace Escandón entre el nativo "bárbaro" y el "dócil y cooperativo" remite al "buen salvaje", aquel que los primeros descubridores y exploradores del Nuevo Mundo, concibieron como carentes de toda maldad y malicia, e incapaces de causar daño alguno, incluso, capaz de asimilar las costumbres europeas y el cristianismo. Al principio del contacto con el nuevo continente, Colón definió a los indios como las mejores gentes del mundo y de la más mansas, así como las más generosas. Les imputó también un buen corazón. Así, argumenta Todorov, el genovés hizo un aporte importante al mito del "buen salvaje". Todorov 47

${ }^{70}$ Se retoma la idea la idea de Alfonso Mendiola que plantea la existencia de un horizonte cultural, que dominó el pensamiento de aquellos cronistas que elaboraron obras o escritos sobre acontecimientos, como el caso de Bernal Diaz del Castillo y su crónica sobre la conquista de Tenochtitlán en 1521. Este aspecto se debe tomar en cuenta al momento de utilizar dichas fuentes, pues permitirá realizar una lectura más crítica y comprensiva de su contenido, y del significado y sentido del texto en el momento de su elaboración. Mendiola, Alfonso. Bernal Diaz del Castillo: verdad romanesca y verdad historiográfica (México: Universidad Iberoamericana-Departamento de Historia, 1995), 137-139.
} 
expuestas a la "tirana esclavitud del demonio", ${ }^{71}$ lo que refleja el peso de las creencias religiosas en aquellos personajes que descubrieron y colonizaron las tierras norteñas. Estos comentarios permiten asomarse un poco a la mentalidad de aquel tiempo que influía en el pensamiento sobre el nativo. La idea de que, dónde no estaba diseminada la religión cristina, era una tierra de "paganos" o de "gentiles" se presenta como un marco referencial para definir al otro, al contrario, al que no comparte las costumbres y creencias. $^{72}$ Esta visión tiene raíces más profundas ya que, retomando a Roger Bartra, el uso de esta fuerte figura y su aplicación a las "sociedades exóticas" del Nuevo Mundo fue producto una amplia circulación del mito del hombre salvaje en Occidente. ${ }^{73} \mathrm{Al}$ definir así a los nativos, Escandón revalora su sentido y su ser, y su misma identidad de hombre civilizado que tiene siempre presente la imagen del "otro". El salvaje se convierte en su sombra, siguiéndole en cada paso que da. Así, la otredad, concepto que está ligado al de la identidad, resulta ser la definición de todo aquello que no somos nosotros, la definición del "otro" ${ }^{74} \mathrm{Al}$ respecto, Carlos Manuel Valdés plantea que en este tipo de fuentes "no hay duda de que escribían sobre el otro al que definía como diferente a ellos mismos, es decir, alguien que no participa de la cultura occidental, cristiana, que no se expresaba en español", y que: "hablaban de ese otro como diferencia más no porque le reconocieran su otredad, lo que equivaldría a una visión tolerante". ${ }^{75}$

Respecto al uso que se le ha dado como fuente en la historiografía, que busca reconstruir las características culturales de los pobladores originarios del ahora estado de Tamaulipas, se tiene que el manuscrito ha influido notablemente. La manera en que Escandón definió a los nativos de la Costa del Seno y la imagen que elaboró sobre ellos, dónde se destaca su supuesto "barbarismo" y "salvajismo", es retomada por algunos estudiosos contemporáneos del pasado indígena de la zona en comento. La información recopilada es plasmada tal cual sin existir una crítica sobre la fuente o una reflexión sobre el sentido y utilidad del manuscrito en el contexto de su producción. ${ }^{76}$ En ciertos casos se les interpreta con base en criterios contemporáneos y se asume una visión de corte evolucionista que reduce a los indígenas a un estado atrasado y de escaso desarrollo cultural. En uno de estos estudios se argumenta que los indígenas que habitaron la zona, ubicada entre el río San Fernando y el río Bravo, fueron “cazadores

\footnotetext{
${ }^{71}$ Escandón y Helguera 58.

${ }^{72}$ Hernández y Guevara plantean que en la producción discursiva elaborada por los funcionarios virreinales acerca de la vida, cultura y los territorios ocupados por los pueblos indígenas, el discurso resultante no solo refiere al "otro", el "indio", sino que se instituye como "una práctica social específica de construcción y significación de la alteridad, en tanto diferencia y desigualdad”, Hernández y Guevara 164.

${ }^{73}$ Roger Bartra, "El Mito del salvaje”, en Ciencias, 61 (2000): 88-92.

${ }^{74}$ Roger 88-89.

${ }^{75}$ Valdés 38 .

${ }^{76}$ Carlos Manuel Valdés argumenta que tras escudriñar un documento respondiendo a preguntas relacionadas con su autor, destinatario, fecha de elaboración, qué relata, cómo se dio ese hecho, sus causas y consecuencias, quién habla tras el escrito, entre otros puntos, se llega al conclusión de que dicha "revisión, análisis, comparación, situación dentro el ambiente que lo generó y su inserción dentro de un espacio geográfico y político" traslada poco a poco aquellos papeles, de lectura simpe a compresión, y finalmente, a una mirada hermenéutica que resulta "netamente interpretativa". Valdés 49.
} 
en llanos y lugares bajos, sin habitación y sin usar el fuego, cubiertos en ocasiones con pieles de venado y coyote", careciendo de asiento fijo. ${ }^{77}$ En otro, se señaló que las poblaciones indias de la franja estaban conformadas por "pequeñas tribus de cazadores recolectores nómadas, de un nivel cultural bajisimo", los cuales se concentraban principalmente en las cuencas de los ríos Bravo, Purificación y Conchos. ${ }^{78}$ No obstante ser fuentes que amplían el conocimiento sobre estas sociedades nativas, parte de los testimonios de militares, funcionarios virreinales y clérigos, que incursionaron en los años tempranos de Nuevo Santander, argumenta Gustavo Ramírez, tienden a confundir, más que aclarar, la cuestión de la filiación étnica de las tribus nativas. ${ }^{79}$ Como se percibe en los dos argumentos anteriores, a dichos aborígenes se les definió de esa manera sin considerar la posibilidad de que su estado, lejos de ser una etapa evolutiva, era una forma de vida resultante de varios siglos de adaptación. ${ }^{80}$

De acuerdo con Carlos Manuel Valdés, las fuentes no deben sustraerse del contexto de su elaboración, particularmente, del proceso de su producción, ya que perderían el sentido para el que fueron elaborados. Considera erróneo pensar que un documento o un texto de un religioso $u$ otro personaje, que recopiló datos sobre grupos nativos o de algunos indígenas en particular, fuera elaborado pensando en un tiempo diferente o para que sirviera como fuente de un estudio histórico de nuestro presente. ${ }^{81}$ Más que describir a los nativos con un enfoque etnológico o antropológico, su interés, por un lado, era dejar constancia de sus actos que le generarían beneficios. Por otro, elaborar un documento que recopilara la mayor parte de información sobre los nativos para que sirviera a los que, posteriormente, establecerían relaciones con ellos, y pudieran alcanzar sus fines políticos, religiosos, militares y económicos. No obstante, el interés de algunos por perseverar los rasgos culturales de los nativos, la mayor parte de los escritos respondieron a una intencionalidad finita. ${ }^{82}$

Al respecto se puede agregar que, tomando en cuenta lo tocante a los supuestos culturales socorridos por Escandón ya referidos, la imagen que plasmó de los nativos del suelo neosantanderino está pensada para su contexto, y para ser leída desde su horizonte cultural, pues busca darles sentido en ese universo lejano a nosotros en tiempo y espacio. Su diario cumple una función: la de informar a los lectores de su época el estado de "barbarie" de los aborígenes y la necesidad de incorporarlos a "las buenas costumbres" lo que, de paso, justificaría su conquista o sometimiento, y su incorporación a la órbita del mundo hispano y la renuncia de su antigua forma de vida. ${ }^{83}$ Resulta necesario "enraizar en los manuscritos, incorporarlos, asumirlos, sostenerlos en su subjetividad y temporalidad contextualizándolos". ${ }^{84}$

\footnotetext{
${ }^{77}$ Saldívar, Gabriel, Los indios.

${ }^{78}$ Eguilaz de Prado 42.

${ }^{79}$ Ramírez 61.

${ }^{80}$ Ramírez 64.

${ }^{81}$ Valdés . 51-52, 55, 58-59.

${ }^{82}$ Valdés 43-48; 221-225.

${ }^{83}$ Mendiola 113.

${ }^{84}$ Valdés 39.
} 
Revelada las bases culturales y contextuales de las que partió Escandón para denominar, describir y distinguir a los indígenas, cuyos aspectos le sirvieron de apoyo para forjar una de las primeras representaciones sobre estos, vale la pena cuestionarse lo siguiente: ¿Qué motivos tendría el coronel para elaborar esta imagen? ¿Qué le incentivó difundir la efigie romántica de cooperativos y dóciles? El siguiente análisis es una propuesta de interpretación sobre lo que subyace tras el discurso del colonizador sobre el territorio y la elaboración de la figura del nativo de la Costa del Seno Mexicano.

\section{La construcción de la imagen: trasfondo y utilidad}

Es probable que la construcción de la imagen del nativo dócil y cooperativo, habitante de la Costa del Seno Mexicano respondiera a los intereses (virreinales, regionales o particulares) que representaba el coronel y la necesidad de justificar su proyecto colonizador. En el manuscrito divulgó esa imagen romántica de los nativos que se aborda este estudio. De acuerdo con los datos citados, la mayor parte de los grupos indígenas del centro del territorio que fueron avistados mostraron un temperamento cordial y afable hacia Escandón y la tropa que lo acompañaba en su inspección. Con excepciones de los citados Janambres, todos ellos mostraron un gran interés por reducirse y congregarse en los pueblos o misiones proyectados por el militar. Varios líderes, según su testimonio, le garantizaron su sujeción y la de los suyos, y mantenerse en quietud hasta su retorno. Situación semejante se registró hacia el norte de la Costa del Seno, en la zona del río Bravo. Según su relato, ahí estableció contacto con los capitanes de las naciones indias que habitaban en las márgenes del torrente, los cuales no fueron identificados por el colonizador, sin embargo, este asentó que habían venido a su encuentro "con las mayores muestras de alegría y satisfacción" y que el "buen trato y regalo" del que fueron objeto, orilló a algunos de ellos a seguirle hasta las "Salinas de la Barra", junto con el referido capitán Santiago. ${ }^{85}$ En cuanto a su congregación, el colonizador asentó que dichos nativos "estaban bien dispuestos" por lo que no había duda de su reducción, poniendo como única condición que no fueran removidos de la zona por haber nacido y crecido en allí. Además, los calificó como incapaces de hacer daño en las fronteras del Nuevo Reino de León. ${ }^{86}$

El fundador anotó que en toda la expedición hecha en el territorio de la Colonia no se presentó “el más leve sin sabor entre soldados ni indios amigos". ${ }^{87}$ Meses después de haber establecido las poblaciones en las orillas del río Bravo, Escandón informó en 1750 que en la villa de Camargo los indígenas congregados cooperaban en la construcción de acequias para suministrar agua. También auxiliaban en la edificación de caminos que comunicarían la referida villa con la proyectada población de Bedoya. Los nativos, señalaba el fundador, eran oriundos de las salinas cercanas a la villa de Reinosa. Escandón también refirió que solamente algunas rancherías de la costa, quienes compartían una isla con un grupo de negros, se mantenían en

\footnotetext{
${ }^{85}$ Escandón y Helguera 41.

${ }^{86}$ Escandón y Helguera 41-42.

${ }^{87}$ Escandón y Helguera 56.
} 
guerra ${ }^{88}$ Estos datos han hecho eco en algunos historiadores contemporáneos, quienes han asumido ese comportamiento de los nativos del río Grande. Gabriel Saldívar postuló que los nativos del río Bravo, partiendo de la villa de Mier, junto con los que ocuparon las cuencas de los ríos Purificación y Conchas (actualmente río San Fernando) fueron "dóciles, poco o nada agresivos, si bien siempre estaban prestos a defender los terrenos que consideraban como suyos", dejando entrever que en algunas ocasiones reaccionaron de manera contraria. ${ }^{89}$ Respecto a esto último, cuando se usan testimonios de militares y misioneros, Carlos Manuel Valdés señala que se deber ser "cuidadoso en cuanto a la credibilidad de tales informes", siendo necesario contrastarlos y compararlos con los datos que ofrece la arqueología y los de otros manuscritos de aquella época. No obstante, enfatiza el autor, es necesario utilizarlos "porque son fuentes importantes para el conocimiento del pasado". 90

Los testimonios sobre la aparente docilidad de los aborígenes del territorio en mención pueden ser matizados, pues dan la sensación de ser un tanto exagerados. Despiertan dudas acerca de que la actitud hostil de los indígenas de la zona hacia los españoles, mostrada en encuentros anteriores, haya cambiado por completo. La imagen del capitán Santiago como un líder al que todos los nativos obedecían, según parece, se amolda a la de un escenario donde todas estas "naciones" indias vivían en completa armonía y que no existían diferencias entre ellas. Este retrato contrasta con el escenario de guerra y disputa relatado tiempo atrás por Alvar Núñez Cabeza de Vaca y Alonso de León. En sus escritos se percibe el contexto que permeaba entre los nativos de la zona, donde la mayor parte de ellos estaba en pugna unos con otros. Cabeza de Vaca hace alusión al aspecto guerrero de estas sociedades, las cuales competían por los recursos de la zona ${ }^{91}$. Esta imagen es importante, porque este aspecto de los pobladores indios relacionado con la guerra, al que también hizo mención Alonso de León. ${ }^{92}$ no fue registrado en los testimonios elaborados en la segunda mitad del siglo XVIII, o quizás, fue ignorado en la mayoría de ellos. A ello se agrega los ataques que solían padecer aquellos aventureros y comerciantes que transitan la zona, previa a su colonización. ${ }^{93}$ La duda sobre esa faceta de "docilidad"

\footnotetext{
88 "Lista de las escuadras, pobladores e indios que va remitiendo don Joseph de Escandón coronel del Regimiento de la ciudad de Querétaro y Teniente de Capitán General en las costas del Seno Mexicano, 1750", Archivo General de la Nación (AGN), sección Colonia, Fondo Provincias Internas, Vol. 172, exp. 17, ff. 309-325, (Nuevo Santander, 1750)

${ }^{89}$ Saldívar 11.

${ }^{90}$ Carlos Manuel 37-38.

${ }^{91}$ El primer viajero refirió un aspecto importante, el contexto que permeaba entre los nativos de la zona del río Bravo, previo al contacto hispano. Relató la dinámica que existía entre los nativos que contactó, a los cuales denomino "flecheros", porque, según Alvar Núñez, la mayoría estaba en pugna unos con otros. Núñez Cabeza de Vaca, Alvar. Naufragios y Comentarios. Apuntes sobre la vida del Adelantado por Enrique Vedía (México: Editorial Porrúa, 1997), 48-50.

${ }^{92}$ León, Alonso de. por su parte, registró el desencuentro que tuvo con los nativos de la zona cuando regresaba de la expedición. Se desató una lucha, sin precisar el lugar y los nativos, solamente se calculó que eran alrededor de 50 y se informó la muerte dos aborígenes y la captura de otros dos.

o México, Estudio preliminar y notas de Israel Cavazos Garza (Monterrey: Centro de Estudios HumanísticosUniversidad de Nuevo León/ Biblioteca de Nuevo León I, 1961), 200-201.

${ }^{93}$ Osante 43-44, 73, 81-82.
} 
de los nativos aludidos se acentúa con el hecho de que, en su viaje de inspección, Escandón hizo escasa referencia a un dato que le fue proporcionado por un intérprete nativo, del cual no dio más detalles. Este testimonio es importante ya que está relacionado con las "confederaciones" y las guerras que tenían entre sí los nativos de las márgenes del río Grande que fueron contactados. ${ }^{94}$ Es decir, ese ambiente de disputa por los recursos de la zona, según parece, seguía presente, siendo probable que la presencia del colonizador y sus planes de fundar poblados permanentes acentuara más ese contexto. Quizás Escandón no ahondó en ese dato, ya que para los fines u objetivos de la expedición no le era favorable informar sobre la existencia de un escenario hostil o de algún rechazo o actitud negativa de los nativos de la zona hacia su proyecto colonizador. Si lo hacía corría el riesgo de que, por un lado, pondría en duda la viabilidad de su empresa y en entredicho el apoyo económico para financiar la llegada de colonos, y por otro, afectaría a estos últimos de manera negativa, ya que, quizás, incidiría en su ánimo de venir a instalarse a la zona por el temor de posibles ataques indios.

Es importante señalar que el proyecto respondía a complejos intereses políticos, económicos y religiosos, que involucraban al colonizador, empresarios y comerciantes, poderosos del centro del virreinato, y autoridades novohispanas ${ }^{95}$. Ubicado en un punto estratégico, la Costa del Seno demandaba desde hacía tiempo su colonización, pues se le veía como un lugar vulnerable, propenso a ser ocupado por alguna potencia europea que le disputaba a España el dominio de estos territorios. Impulsar el proyecto de Escandón y consentir la población hispana del Seno, ${ }^{96}$ subsanaría este temor y serviría de baluarte para cualquier intento de invasión extranjera. Así mismo, el territorio ofrecía la posibilidad de establecer grandes núcleos poblacionales y desarrollar haciendas dedicadas al cultivo o la cría de ganado de todo tipo, ${ }^{97}$ lo que generaría importantes ingresos a la Hacienda por los tributos que devengaría y ofrecería a los colaboradores la oportunidad de acrecentar sus peculios explotando las tierras y las salinas de la zona. Otro importante recurso para explotar serían las vetas de plata que, se presumía, ${ }^{98}$ eran abundantes en las montañas que dominaban el paisaje. No menos importante, lo era también la difusión de la religión occidental, y el rescate de la "tirana esclavitud" del demonio que, según se decía, padecían las almas de cientos de nativos. ${ }^{99}$ Con todos estos intereses en juego, resulta lógico pensar que Escandón manejó el discurso sobre los nativos y el paisaje de la Costa en beneficio del proyecto colonizador aludido.

Respecto al caso del citado líder indígena Santiago, mismo que resalta del resto de los cabecillas asentados en el diario, este fue descrito por Escandón como de "bizarro cuerpo, temido y respetado entre los suyos", y que poseía un claro

\footnotetext{
${ }^{94}$ Escandón y Helguera 37.

${ }^{95}$ Osante 9-10.

${ }^{96}$ Escandón y Helguera 51.

${ }^{97}$ Escandón y Helguera 50.

${ }^{98}$ Escandón y Helguera 51.

${ }^{99}$ Escandón y Helguera 58.
} 
entendimiento y que era muy afecto a los españoles. El colonizador, como antes se mencionó, le otorgó ropa y regalos y señaló que este por medio de señales de humo llamó a su gente. ${ }^{100}$ Sin embargo, no queda claro quiénes eran los suyos o su gente, ya que no refirió a que "nación" india perteneció el adalid. Algunos historiadores que abordaron la identidad del capitán indígena plantean que este había relevado a otro líder conocido como Pedro Botello, sin embargo, no se aluden más datos sobre su supuesta docilidad y amabilidad, y del apoyo otorgado al colonizador durante su viaje de inspección. ${ }^{101} \mathrm{Su}$ identificación se presta a confusiones, ya que el apelativo de Santiago no era exclusivo del referido adalid, ya que dicho nombre fue registrado o aplicado a nativos de otras zonas del territorio. Al caso, en un documento que data de 1748, aproximadamente, se registró a los "guajalote", compuesto por 60 familias, quienes se ubicaban "en el camino recto para las salinas de la Barra", cuyo capitán era un tal Santiago. Otra etnia, denominada "boca prieta", también fue asociada a otro cabecilla Santiago, la cual se ubicada al sur del río Grande, en las adjuntas y nacimiento del río Soto la Marina y rumbo a la costa, en el centro de la provincia. ${ }^{102}$

En lo que toca a quiénes eran los hispanos que, según Escandón, Santiago apreciaba y en qué lugar se ubicaban no queda claro en el manuscrito. Asumiendo que el capitán y los hermanos Cantú e intérpretes indios, quienes llegaron acompañados por el líder nativo, provenían de Linares, es probable que Escandón se refiriera a los pobladores de dicha villa. Sin embargo, surgen dudas sobre ese afecto, ya que, si vistió a Santiago, es porque debió andar desnudo. Esto parece ser contradictorio, ya que si existió esa afinidad tuvo que ser resultado de un largo contacto de Santiago con los pobladores o producto de su congregación en alguna misión, lo cual influiría en algunas de sus costumbres, como el andar desnudo. Esta faceta fue una de las más combatidas por los hispanos, de allí que el regalar vestido a los nativos fuera una práctica muy socorrida.

Por otra parte, Escandón señaló que todas las poblaciones indias de las riberas sur del citado río Bravo, aunque tenían un capitán que las gobernaba en ausencia de Santiago, reconocían a este último como su líder y le obedecían. Según parece, su influencia era extensa ya que los nativos de la otra banda del río, (la parte norte localizada en lo que ahora es Texas) también le reconocían como tal. ${ }^{103} \mathrm{Si}$ estas

\footnotetext{
${ }^{100}$ Escandón y Helguera 37.

101 Saldívar señaló que Santiago procedía de la sierra Tamaulipa Oriental o la Vieja, y se movilizaba constantemente "desde la barra de Maupat (Soto la Marina) hasta las lagunas del norte del río Bravo y desde la sierra nombrada (Tamaulipa Vieja) hasta más allá del Bravo en tierras que ahora están frente a Camargo y Mier", Saldívar 7. Isabel Eguilaz, por su parte, calificó al capitán Santiago como el de "mayor personalidad", a quien obedecían "todos los grupos que habitaban desde el río de la Purificación hasta la banda norte del río Bravo", y asentó que dicho líder había sustituido a Botello en el mando después de 1733, Eguilaz de Prado 91-92.

${ }^{102} \mathrm{El}$ documento recopiló es una lista de indígenas que habitaron en la referida Costa del Seno mexicano, el cual Saldívar anexa en su obra. Saldívar 31-34.

${ }^{103}$ Escandón y Helguera, José de, 1747 Informe para..., 42. Los datos sobre Santiago, particularmente este último relacionado con su amplio liderazgo, han hecho eco en algunos historiadores. Saldívar le atribuye esa potestad, que heredó de otro cabecilla indígena llamado Juan Botello. Saldívar 7. De manera semejante lo describen otros autores, Eguilaz de Prado 91; Ramírez 61.
} 
etnias estaban sujetas a Santiago, llama la atención que un líder indígena con amplia influencia pasara desapercibido por las autoridades de las provincias del Nuevo Reino de León y Texas, colindantes con el territorio del Seno Mexicano, lo que hace dudar de ese supuesto liderazgo tan amplio. ${ }^{104}$

A lo largo de su relato, Escandón no registra dato alguno de algún encuentro desafortunado con los nativos del territorio, y muestra una imagen de docilidad y cooperativismo, incluso, señaló que estos le apoyaron en su inspección mostrándole rutas por donde seguir y la ubicación de suministros de agua o aguajes. Al contrastar esta información con testimonios posteriores a la fundación de la Colonia de Nuevo Santander, la imagen romántica comienza a tambalearse al reportarse choques que se suscitaron entre los acompañantes del colonizador y ciertas tribus durante la institución de algunas de las villas. Tal es el caso del testimonio de fray Simón del Hierro, quien elaboró un diario donde se develan tales vicisitudes. En su escrito la figura del citado líder Santiago se pierde, ya que no es mencionado. Es raro, ya que, según Escandón, Santiago sería uno de los principales apoyos para lograr la reducción de los nativos de la zona. ${ }^{105}$ Esa supuesta colaboración y afinidad del líder indígena Santiago queda en entredicho con el testimonio que refiere su muerte a manos de los españoles. Según Isabel Eguilaz, referida antes, Santiago había tenido "violentos encuentros con los conquistadores", muriendo en uno de ellos, según parece, ahorcado a manos de los hispanos. ${ }^{106}$ No se explica cómo después de haberle auxiliado, Escandón haya permitido su ejecución, o quizás fue algo concertado para deshacerse del cabecilla, el cual podría representar un serio peligro para el avance de la colonización. ${ }^{107}$

A pesar de que del testimonio de Escandón se desprende que algunos de los jefes indios contactados tenían influencia sobre varios grupos, es una visión que puede matizarse, pues es más probable que los nativos de la Costa no conformaran

\footnotetext{
${ }^{104}$ Mirafuentes Galván recopila la mayor parte de los documentos relacionados con ataques y alzamientos indígenas, registrados en las provincias de Coahuila, Nuevo Reino de León, Texas y la Colonia de Nuevo Santander. En algunos de esos escritos se identifica el nombre de los líderes indios de los grupos nativos en pugna, y el de los que pactaron con los españoles. A diferencia de otros cabecillas indígenas de la colonia, como Guardado, Panchuelo y Pedro José, el apelativo de Santiago no es aludido, Mirafuentes Galván, José Luis. Movimientos de resistencia y rebeliones indigenas en el Norte de México (1680-1821). Guía Documental III. (México, Universidad Nacional Autónoma de México, 2004), 109-165.

${ }^{105}$ Una de las fundaciones proyectadas fue ubicada en el llano de las Flores, cercano al sitio donde el río Grande se une con el río San Juan. Esta población fue bautizada con el nombre de Camargo, y se pensó que sería muy apropiada para que, por medio del referido capitán Santiago, se congregaran algunas de las rancherías registradas por el colonizador. Escandón y Helguera, José de, 1747 Informe para, Op. Cit., p. 68.

${ }^{106}$ Según la autora, el capitán de la villa de Santander emprendió una operación militar contra nativos de la sierra Tamaulipa la Vieja, de los cuales no se especificó su apelativo o filiación. Estos huyeron al llegar a las faldas de la citada sierra, por lo que el oficial dejó pendiente la campaña y se avocó a seguirlos, y con este pretexto, "volvió las armas contra la ranchería del indio Santiago, donde estando él y los suyos sin esperarlos, dieron sobre ellos, cogieron a dicho capitán y lo ahorcaron y mataron a otros", Eguilaz de Prado 91-92

${ }^{107}$ Santiago no fue el único líder indígena de la Costa del Seno, que fue eliminado. Una vez fundada la Colonia de Nuevo Santander, las tropas hispanas bajo el mando Escandón, en su calidad de gobernador de esta provincia, terminaron con la vida de otros cabecillas, como los llamados Pachón y Guardado, ambos pertenecientes a los Janambres, Olvera 42-45.
} 
grandes unidades políticas, como el caso de otra sociedades nativas, apaches y comanches, por ejemplo. ${ }^{108}$ Resulta más viable que la identificación o alusión de este tipo de líderes con amplia influencia, en el caso que se aborda, respondiera a los intereses asociados al viaje de reconocimiento y a las necesidades que tenía Escandón de mostrar que había sido capaz de incorporar a su proyecto colonizador a un líder con amplia influencia. No sería descabellado pensar que la alusión a Santiago y su imagen obedeciera al interés del colonizador de querer mostrarle al virrey y el resto de los funcionarios, la existencia de un líder "general" en la zona, cuya sujeción, ya sea por medios coercitivos o por voluntad propia, garantizaría la sumisión del resto de los pobladores indios y la viabilidad de su empresa colonizadora, así como la libre explotación de los importantes recursos naturales referidos en su viaje de inspección. Semejante situación podría aplicarse al referido líder Marcos Villanueva.

De acuerdo con Carlos Manuel Valdés, los textos coloniales fueron elaborados como parte de las funciones de los representantes de las variadas instituciones, que conformaron la estructura administrativa del virreinato. Su redacción fue pensada en su presente, es decir en el contexto de su creación, pues cumplían una función dentro de esa estructura. ${ }^{109}$ Servían como puntos de referencia para la elaboración de leyes, instrucciones, ordenanzas, bandos, decretos, y otros documentos que dieron forma a la política que se ensayó con los nativos. ${ }^{110}$ Respondieron a una situación de ese momento, a lo que se requería y era urgente saber del "otro" para poder, de acuerdo con quién elaboró el documento y para qué autoridad, cristianizarlo con mejor eficacia, someterlo con menor esfuerzo o, en el peor de los casos, justificar su aniquilación ${ }^{111}$.

Por otra parte, el hecho de que Escandón en su informe señalara la existencia de grandes extensiones de tierras, ausentes de labranza y con potencial inmenso para ser explotadas libremente, y habitadas por nativos "bárbaros" e "incivilizados", sin sujeción alguna a las leyes cristianas, puede darle al diario el aspecto de un documento legal que, por un lado, justifica su poblamiento y ocupación por parte de España y, por otro, sirve de probanzas y méritos a favor del coronel, quien a costa de arriesgar su vida, se adentró en ese territorio calificado de agreste y peligroso junto con sus pobladores autóctonos. ${ }^{112}$ Así, el manuscrito se sumaría a los documentos que Escandón generó por medio de la relación de las batallas y enfrentamientos que sostuvo con los indígenas insumisos y alzados de la Sierra Gorda, y posteriormente, Nuevo Santander. ${ }^{113}$

\footnotetext{
${ }^{108}$ Olvera 77-85.

${ }^{109}$ Valdés 58-60.

${ }^{110}$ Valdés 43-46, 48.

111 Valdés 37-38, 48.

${ }^{112}$ Mendiola 142-143.

${ }^{113}$ Siguiendo a Mendiola, debido a exigencias de orden legal, los soldados fueron impulsados a llevar memoria de sus actos militares, lo más detallada posible, Ibid.
} 
Con base en lo planteado por Alfonso Mendiola, el hecho de tratar de situar el diario de Escandón en su propio horizonte cultural busca matizar el uso que le ha dado en la historiografía contemporánea que versa sobre el proceso colonizador de Nuevo Santander y sobre sus pobladores nativos. En algunos casos se tiende a descontextualizar el manuscrito y se pasa por alto que fue elaborado para un tiempo determinado y con fines específicos que tienen sentido para esa temporalidad y que ha pasado por un proceso de producción y elaboración, que responde al contexto del avance hispano en América. No se desvalora la importancia que detenta el escrito como testimonio de primera mano, sino que se comparte el juicio de Mendiola respecto al uso acrítico como fuente de la investigación historiográfica actual. De ahí que el autor sugiera que este tipo de escritos se conciban como productos culturales, y no atemporales. ${ }^{114}$

Para cerrar este apartado, si en efecto los nativos de las márgenes del río Grande fueron dóciles y cooperativos, no se entiende por qué de todos modos Escandón estableció una escuadra militar en la villa de Reinosa y erigió un presidio en la de Camargo; ambas tropas servirían para contener cualquier irrupción o alzamiento en la zona. En el mismo sentido, sí en efecto las muestras de afinidad y concordia que el colonizador pregonó constantemente en su reporte se presentaron, no se explica porque empleo una política de sometimiento y reducción de los nativos basada en la "guerra a sangre y fuego" durante la fundación de las villas y, posteriormente, en su calidad de gobernador de la Colonia. ${ }^{115}$ Mucho menos se concibe la creación de una estructura militar compuesta por 12 escuadras y una compañía volante para proteger las poblaciones y sus moradores, y someter a los indígenas insumisos que, supuestamente eran pocos o no los había en el territorio de la Costa del Seno Mexicano. ${ }^{116}$

\section{Reflexiones finales}

El descubrimiento del Nuevo Mundo abrió un campo fértil para los viajes de exploración que, en un principio, tuvieron como eje las expediciones marítimas. Surcar los mares se convirtió en un atractivo para aquellos europeos que fincaron sus esperanzas de progreso en las nuevas tierras del orbe desconocido. El contacto con las costas de lo que aún no se percibía como un nuevo continente, generó la posibilidad de adentrarse en sus territorios internos, y dar paso a los viajes por tierra, que culminaron con la conquista de Tenochtitlán, y posterior fundación de la Nueva España. Derivado de este proceso de expansión colonial hispana se elaboraron varios escritos, entre ellos, crónicas, informes militares y diarios de viaje. Estos testimonios, relacionados con las expediciones que se realizaron bajo el marco del proceso del avance ibérico, se han convertido en una importante fuente para la historiografía contemporánea. Son retomados como sustento primordial para historiar dicho empuje colonial, abordar

\footnotetext{
${ }^{114}$ Mendiola 113.

${ }^{115}$ Olvera 33-44.

${ }^{116}$ Osante, 119-121. Hacia 1775 bajo el mando de Escandón operaba en la Colonia de Nuevo Santander una tropa militar compuesta por 144 efectivos, entre oficiales y soldados. Olvera Charles, Fernando. "Las Reformas Borbónicas y su impacto en la estructura militar de la Colonia de Nuevo Santander, 1750-1796", en Septentrión, 5 (2010): 9.
} 
el espacio geográfico y físico previo a la llegada de los españoles, y reconstruir las características culturales de los pobladores originarios del México actual.

Este artículo entra en el debate de la viabilidad de estas fuentes para reconstruir acontecimientos pasados o la vida de sociedades pretéritas, en este caso, los aborígenes del estado actual de Tamaulipas. Sin ánimo de demeritar las obras de los autores enunciados, en este artículo, se cuestiona el uso de los citados testimonios de manera acrítica, como es el caso del informe del viaje de reconocimiento de la llamada Costa del Seno Mexicano, realizado en 1747 por Jose de Escandón; quien fundaría en ese espacio la Colonia de Nuevo Santander. Testimonios como el del militar, y otros más, que recopilan datos sobre la población aborigen, han sido dimensionados confiriéndoles cualidades, como otorgarles un sentido etnológico o antropológico y calificando a ciertos autores como "padres" de ambas disciplinas, o fundadores. Su uso e interpretación, no en todos los casos, ha partido de horizontes contemporáneos de los ensayistas. Es decir, abordan su contenido con ojos del presente o parámetros actuales, lo que, en ocasiones, hace que descontextualicen la información que los testimonios coloniales ofrecen, y provoca una lectura poco reflexiva de su contenido. Respondiendo a esta inquietud, se ha intentado esbozar una mirada crítica y analítica sobre el citado diario, que escudriñe aquellos elementos que influyeron para que Escandón definiera así a los nativos de la Costa del Seno.

El texto devela cómo las categorías político-sociales impuestas a los aborígenes con base en el comportamiento mostrado ante la colonización de sus antiguos territorios, generó en el colonizador una visión preconcebida de los habitantes del Seno. Epítetos como "indios bárbaros", “chichimecos” y "apóstatas”, relacionados con su forma de vida tradicional y su rechazo a las costumbres hispanas y creencias cristianas se combinaron con otros términos como los de "indios amigos", "auxiliares" o "cristianos", aplicado a aquellos que se habían sujetado al español y aceptado el cristianismo, para definir al otro, representado por las incontables etnias que los hispanos contactaron durante la conquista y colonización de tierras norteñas. Tales calidades alimentaron su pensamiento despectivo hacia la población nativa. Queda claro cómo su propia experiencia, que le dejó la "pacificación" de la Sierra Gorda, influirá para que asumiera como infalibles esas visiones. Es viable señalar que no solo la experiencia que deja el trato con las personas alimenta las definiciones quede ellas se elaboran. Influye también el contexto, el imaginario que subsiste y que impone criterios para definir al otro, al contario. En Escandón aflora ese pensamiento cuando define como "barbaros e incivilizados" a los nativos de la Costa del Seno, por el hecho de andar desnudos, vivir errantes y sin ninguna ley o religión que los gobernara. Así, a partir de mitos y tradiciones de corte europeo, de largo arraigo, Escandón los define a partir de sí mismo y de lo que él representa: el mundo civilizado occidental. De esta forma, explica el sentido y posición de los autóctonos en el universo de su tiempo, el lugar de aquellos diferentes.

Ha quedado evidenciado cómo una combinación de variados factores políticos, económicos y culturales, que permeaban el horizonte del militar, impulsaron y alimentaron las primeras imágenes elaboradas sobre los nativos que se abordan que, 
sea dicho de paso, tenían sentido y utilidad en aquel universo, lejano a nosotros en tiempo y espacio. El que destacara en su informe la ausencia de rasgos “civilizados" en los nativos, y resaltara aquellos que acentuaban su atraso, respecto a otras sociedades nativas contactadas antes por los españoles, tuvo fines utilitarios para su momento. Su desnudez, su hábitat en los montes, sierras y valles, la ausencia de prácticas agrícolas y supuesto "barbarismo", buscaba mostrar que incorporarlos al mundo hispano, les sería más beneficioso que negativo, y que redundaría en un mejor servicio ambas majestades: el rey y Dios. Así, dicho estado de los nativos demandaba urgentemente su incorporación a la órbita hispana para encauzarlos en la religión y así, como lo dijera el propio Escandón, liberar "sus almas de la tiranía del Demonio". La alusión a una vida salvaje o silvestre, y la definición de bárbaros, apuntaba a justificar la ocupación del territorio, pues en esa situación los nativos no aprovechan, ni explotaban al 100 por ciento los abundantes recursos naturales que la Costa del Seno poseía, así mismo, la visión romántica de unos nativos "dóciles y cooperativos" con líderes que habían ofrecido su apoyo al colonizador, pretendía apuntalar la empresa colonizadora y hacer viable el apoyo de las autoridades novohispanas y demás personajes que invertirían recursos en la colonización del territorio.

\section{Bibliografía}

\section{Fuentes primarias}

\section{Archivos}

Archivo General de la Nación (AGN), Sección Colonia, Fondo Provincias Internas.

Escandón, José de. Reconocimiento de la costa del Seno mexicano. Archivo de la Historia de Tamaulipas, 1 ${ }^{\mathrm{a}}$. serie, Vol. 2. México: Editor y compilador Gabriel Saldívar, 1946.

\section{Libros}

Escandón y Helguera, José de. 1747 Informe para reconocer, pacificar y poblar la Costa del Seno Mexicano. Introducción, paleografía y notas por Juan Díaz. Ciudad Victoria: Consejo Estatal para la Cultura y las Artes en Tamaulipas/Gobierno de Tamaulipas, 1999.

León, Alonso de. Historia de Nuevo León con noticias sobre Coahuila, Tamaulipas, Texas y Nuevo México. Estudio preliminar y notas por Israel Cavazos Garza. Monterrey: Centro de Estudios Humanísticos-Universidad de Nuevo León/ Biblioteca de Nuevo León I, 1961.

Núñez Cabeza de Vaca, Alvar. Naufragios y Comentarios. Apuntes sobre la vida del Adelantado por Enrique Vedía. México: Editorial Porrúa, 1997. 
Vaz de Caminha, Pero. Carta del descubrimiento de Brasil. Traducción del portugués y prólogo por Isabel Soler. Barcelona: Acantilado. Quaderns Crema, S.A.U, 2009.

\section{Fuentes secundarias}

\section{Libros}

Álvarez, Salvador, El indio y la sociedad colonial norteña, siglos XVI-XVIII. México: Colegio de Michoacán/ Instituto de Investigaciones Históricas-Universidad Juárez del Estado de Durango, 2009.

Bartra, Roger. El salvaje en el espejo. México: Universidad Nacional Autónoma de México/Era, 1992.

Cavazos Garza, Israel, Nuevo León y la colonización de Nuevo Santander. Monterrey: Sindicato Nacional de Trabajadores de la Educación, 1994.

Dussel, Enrique.1492 El encubrimiento del Otro. Hacia el origen el mito de la modernidad. La Paz: Plural Editores/Universidad Mayor de San Andrés, 1994.

Eguilaz de Prado, Isabel. Los indios del Nordeste de Méjico en el siglo XVIII. Sevilla: Facultad de Filosofía y Letras-Universidad de Sevilla, 1965.

Fontana, Josep. Europa ante el espejo. (Barcelona: Editorial Critica, 2000).

Herrera Pérez, Octavio. Breve Historia de Tamaulipas. México: El Colegio de México/ Fondo de Cultura Económica, 1999.

Herrera Pérez, Octavio, Tamaulipas a través de sus regiones y municipio. Tomos I-IX. México: Agencia Promotora de Publicaciones/Gobierno del Estado Libre y Soberano de Tamaulipas, 2014.

Hill, Francis Lawrence, José de Escandón and the founding of the Nuevo Santander. Ohio: State University Press, Columbus, 1926.

Lara Cisneros, Gerardo. El Cristo viejo de Xichú. Resistencia y rebelión en la Sierra Gorda durante el siglo XVIIII. México: Instituto de Investigaciones HistóricasUniversidad Autónoma de Tamaulipas, 2007.

Meade, Joaquín. Don José de Escandón, conde de Sierra Gorda, Monterrey: Universidad Autónoma de Nuevo León, 1948.

Mendiola, Alfonso. Bernal Diaz del Castillo: verdad romanesca y verdad historiográfica. México: Universidad Iberoamericana-Departamento de Historia, 1995. 
La visión del otro en el viaje de reconocimiento de la Costa del Seno Mexicano de José de...

Mirafuentes Galván, José Luis. Movimientos de resistencia y rebeliones indígenas en el Norte de México (1680-1821). Guía Documental III. México, Universidad Nacional Autónoma de México, 2004.

Olvera Charles, Fernando. "Sobrevivir o fenecer en el noreste novohispano". Estrategias de los indígenas ante la colonización y su incidencia en el comportamiento de la resistencia nativa en Nuevo Santander, 1780-1796. San Luis Potosí: Colegio de San Luis/UAT, 2019.

Osante, Patricia. Orígenes del Nuevo Santander, 1748-1772. México: Universidad Nacional Autónoma de México/ Instituto de Investigaciones HistóricasUniversidad Autónoma de Tamaulipas, 1997.

Prieto, Alejandro, Historia, Geografía y estadística de Tamaulipas. México: Tipografía Escalerillas núm. 3, 1873.

Ramírez Castilla, Gustavo Antonio. Panorama arqueológico de Tamaulipas. Cd. Victoria: Gobierno del Estado de Tamaulipas/Instituto Tamaulipeco para la Cultura y las Artes, 2007.

Saldívar, Gabriel, Historia Compendiada. México: Gobierno del Estado de Tamaulipas, 1945)

Saldívar, Gabriel. Los indios de Tamaulipas. México: Instituto Panamericano de Geografía e Historia, 1943.

Salinas, Martin. Indígenas del delta del río Bravo. Su papel en la historia del sur de Texas y el noroeste de México. Ciudad Victoria: Instituto de Investigaciones Históricas-Universidad Autónoma de Tamaulipas, 2012.

Stresser-Péan, Guy, San Antonio Nogalar: la sierra de Tamaulipas y la frontera noreste de Mesoamérica. México: Centro de Investigaciones y Estudios sobre Antropología Social/Colegio de San Luis/Universidad Autónoma de Tamaulipas/ Centro Frances de Estudios Mexicanos y Centroamericanos, 2000.

Todorov, Tzvetan. La Conquista de América el problema del otro. (México: Siglo XXI Editores, 1998).

Toribio de la Torre et al, Historia General de Tamaulipas. Cd. Victoria, Tamaulipas: Instituto de Investigaciones Históricas -Universidad Autónoma de Tamaulipas, 1986.

Valdés, Carlos Manuel. Los bárbaros, el rey y la iglesia. Saltillo: Universidad Autónoma de Coahuila, 2017. 
Zorrilla, Juan Fidel y Salas, Carlos, Diccionario Biográfico de Tamaulipas. México: Editorial Jus/Universidad Autónoma de Tamaulipas, 1984.

Zorrilla, Juan Fidel; Herrera, Octavio; Miró, Maribel; Tamaulipas. Una historia compartida I, 1810-1921. México: Instituto de Investigaciones HistóricasUniversidad Autónoma de Tamaulipas/Instituto José Luis María Mora, 1993.

Zorrilla, Juan Fidel, Familias políticas dominantes de Tamaulipas. Ciudad Victoria: Instituto de Investigaciones Históricas-Universidad Autónoma de Tamaulipas, 1996.

\section{Artículos de revista}

Bartra, Roger. "El Mito del salvaje”, Ciencias, 61 (2001).

Bustamante, Jesús. "La invención del indio americano y su imagen: cuatro arquetipos entre la percepción y la acción política", Nuevo Mundo Mundos Nuevos (2020).

Carneirò, Sarissa, "Mujer y alteridad en los discursos lusitanos coloniales sobre Brasil del siglo XVI: reelaboraciones, desplazamientos", Lucero, 17 (2006).

Cunningham, Debbie S. "Los nativos del Seno Mexicano documentados en los manuscritos de Escandón y Hierro de 1747-1749 (1)", Southern Quarterly, 51, 4 (2014).

Hernández Casillas, H., y Guevara Zárraga, M. E. "Las posibilidades del análisis crítico del discurso en el seguimiento de estructuras discursivas de dominación en documentos coloniales. El caso del Manifiesto de Eusebio Bentura Beleña, Nueva España”, Antigua Matanza. Revista de Historia Regional, San Justo, Universidad Nacional de la Matanza, 4, 2 (2020).

Mora Rodríguez, Luis Adrián. "Imaginarios del otro en la conquista. La construcción polimórfica del indio en la Apologética Historia Sumaria de Bartolomé de Las Casas", Realis, Revista de Estudos Antiutilitaristas e Poscoloniais, 5, 2 (2015).

Lopes de Carvalho, Francismar Alex. "Imagens dos índios na Amazônia espanhola, nos séculos XVI e XVII”, Revista de Indias, 78, 274 (2018).

Olvera Charles, Fernando. "Las Reformas Borbónicas y su impacto en la estructura militar de la Colonia de Nuevo Santander, 1750-1796", en Septentrión, vol. 5, 2010 .

Ortelli, Sara, “¿Apaches hostiles, apóstatas rebeldes o súbditos infidentes? Clasificaciones etnopolíticas en la Nueva Vizcaya de la segunda mitad del siglo XVIII”, Anuario, 21 (2006). 
La visión del otro en el viaje de reconocimiento de la Costa del Seno Mexicano de José de...

Solodkow, David M. "De caníbales, etnógrafos y evangelizadores: versiones de la Otredad en las primeras cartas del "Descubrimiento" (Cristóbal Colón [1493], Michele de Cuneo [1495] y Pêro Vaz de Caminha[1500])", en The Colorado Review of Hispanic Studies, 3 (2005).

Vázquez García, Gabriela. "José de Escandón y las nuevas poblaciones del Nuevo Santander”, Scripta nova, X, 85 (2006).

\section{Tesis, ponencias y otros}

Cunningham, Debbie S. La exploración y colonización preliminar del Seno Mexicano bajo don José de Escandón (1747-1749): un análisis basado en manuscritos españoles primarios (tesis doctoral), TA\&MU, 2010.

Olvera Charles, Fernando. Las incursiones lipanes y comanches en Nuevo Santander, 1750-1800 (tesis doctoral), UNAM, 2017.

Solodkow, David M. Etnógrafos coloniales: escritura, alteridad y eurocentrismo en la conquista de América. (Tesis doctoral), Vanderbilt University, 2009. 